\title{
Conservation of the Land Walls Protection Area by Renewal (!): Evaluating the Spatial Effects of the Law No. 5366 Through "Zeytinburnu Culture Valley Project" of Istanbul
}

\author{
Kara Surları Dünya Miras Alanı'nı Yenileyerek Koru-ma (!): 5366 Sayılı Yasa'nın \\ Mekansal Etkilerini İstanbul "Zeytinburnu Kültür Vadisi Projesi” Üzerinden Yorumlamak
}

\author{
Elifnaz DURUSOY ÖZMEN, Mehmet Cengiz CAN
}

\section{ABSTRACT}

The urban transformation process accelerated immensely by the end of the $20^{\text {th }}$ century is one of the problems Turkey has faced. This process, which is guided by various legal and administrative sanctions for many years, affects historical urban areas negatively. One of these sanctions providing a basis for inappropriate interventions on the historical urban areas is the Law No. 5366 on "Conservation by Renovation and Use by Revitalization of the Deteriorated Historical and Cultural Immovable Property". This law, the "Renewal Law" in short, carried into effect in 2005, causes irreversible damages and losses through the renewal of the qualified urban sites. The purpose of this study is to critically evaluate the urban transformation of the "Land Walls Protection Area", one of four sites determined as world heritages in the Historical Peninsula of Istanbul, through a reading of the Law No. 5366. This evaluation is made through "Zeytinburnu Culture Valley Project", which is the largest renewal project identified among the six renewal zones falls within the Land Walls Protection Area. The paper begins with the history of Zeytinburnu through a chronological narration. After emphasizing the values of the district, "Zeytinburnu Culture Valley Project" is introduced in terms of its purpose, scope and content. The study then focuses on the spatial effects of Law No. 5366 through the final state of the project. Lastly, on its $13^{\text {th }}$ year of force, the consequences of the Renewal Law on the cultural heritage that needs to be protected are specified in the light of the internationally valid charters from a conservation point of view.

Keywords: Conservation; Land Walls Protection Area; Renewal Law No. 5366; urban transformation; Zeytinburnu Culture Valley Project.

Öz

20. yüzyılın sonuyla birlikte hızlı bir gelişim gösteren kentsel dönüşüm süreci, Türkiye'nin deneyimlemekte olduğu sorunların başında gelmektedir. Uzun yıllar boyunca çeşitli yasal ve yönetsel yaptırımlarla yönlendirilen bu süreç, tarihi kentsel alanların olumsuz yönde etkilenmesine neden olmaktadır. Belirtilen uygunsuz müdahalelere zemin oluşturan yaptırımlardan biri de 2005 yılında kabul edilen 5366 Sayılı "Yıpranan Tarihî ve Kültürel Taşınmaz Varlıkların Yenilenerek Korunması ve Yaşatılarak Kullanılması Hakkında Kanun"dur. Kısaca "Yenileme Kanunu" adıyla anılan bu kanun, sit alanı olarak korunan nitelikli kentsel dokularda geri döndürülmesi güç, hatta imkansız kayıplara sebebiyet vermektedir. Bu çalışmanın amacı, üstün evrensel nitelikleri dolayısıyla İstanbul'un Tarihi Yarımada'sı içerisinde belirlenen dört adet dünya miras alanından biri olan "Kara Surları Koruma Alanı"nın deneyimlediği kentsel dönüşümü 5366 Sayılı Kanun çerçevesinde değerlendirmektir. Belirtilen değerlendirme, uluslararası ölçekte korunan bir kültür varlığı olan "Kara Surları Dünya Miras Alanı" dahilinde 5366 Sayılı Kanun kapsamında belirlenen altı adet yenileme alanından en büyüğü olan "Zeytinburnu Kültür Vadisi Projesi" üzerinden yapılmıştır. Makale kapsamında ilk olarak Zeytinburnu'nun kısa tarihçesi ile bölgenin sahip olduğu değerler aktarılmıştır. Ardından, 5366 Sayılı Kanun'un alan üzerindeki mekânsal etkileri; amaç, kapsam ve içerik bakımından tanıtılan "Zeytinburnu Kültür Vadisi Projesi" aracılığıyla vurgulanmıştır. Çalışmanın son bölümünde ise 13 yıldır yürürlükte olan 5366 Sayılı 'Yeni'leme Kanunu'nun korunması gerekli kültür varlıkları üzerindeki etkileri uluslararası geçerliliğe sahip belgeler ışığında koruma bakış açısı ile yorumlanmıştır.

Anahtar sözcükler: Koruma; Kara Surları Koruma Alanı; 5366 Sayılı Yenileme Yasası; kentsel dönüşüm; Zeytinburnu Kültür Vadisi Projesi.

Department of Architecture, Yıldız Technical University Faculty of Architecture, İstanbul, Turkey

Article arrival date: March 22, 2018 - Accepted for publication: August 25, 2018

Correspondence: Elifnaz DURUSOY ÖZMEN. e-mail: e.durusoy@hotmail.com

๑ 2018 Yıldız Teknik Üniversitesi Mimarlık Fakültesi - ๑ 2018 Yıldız Technical University, Faculty of Architecture 


\section{Introduction: Istanbul and the Land Walls Protection Area}

Istanbul has always been at the spotlight in terms of the qualities it has possessed throughout Byzantion, Roman, Byzantine, Ottoman and Turkish Republican periods. Preserving the capital status until the $20^{\text {th }}$ century, it has indeed been one of the centres of power from where significant political and economic decisions were taken for centuries. Despite the frequently experienced disasters, the city managed to keep the material traces of uninterrupted spatial development due to its geopolitical position up to the present.

One of those permanent settlement areas in Istanbul is the Historical Peninsula, where the first traces of human habitation can be dated back to 8500 B.C. Throughout its history, various structures were developed to defend this particular area bounded by Golden Horn in the north, by Bosphorus in the south and the east and by Zeytinburnu, Eyüp and Bayrampaşa districts in the west. One of the significant tools to defend the city against external attacks were the "city walls", constituted by the Byzantion Walls, the Septimus Severus Walls, the Constantinian Walls, the Theodosian Walls, the Marmara Walls, the Golden Horn Walls and the Anastasian Walls (Fig. 1). ${ }^{1}$

Only, the Theodosian Walls, which are also known commonly as the "Land Walls", differ from the others as having 'world heritage' status. The Land Walls, which were built by Theodosius II, provide a 6650-meter long terrestrial defence line making up the inner wall, the outer wall and the moats, as well as the towers and the bastions located at different elevations [URL-1] (Fig. 2). ${ }^{2}$ Due to the underlined unique configuration, the Land Walls together with their immediate environment have exemplified a leading reference for military architecture. In virtue of this "Outstanding Universal Value (OUV)", an area of 548 hectares that includes parts from Fatih, Eyüp and Zeytinburnu districts was inscribed to the UNESCO World Heritage List with the name of "Land Walls Protection Area" in 1985 [URL-1]. ${ }^{3}$ This area, along with three other inscribed sites, constitutes the "Historic Areas of Istanbul World Heritage Site" (Fig. 3). ${ }^{4}$

The purpose of this study is to evaluate the urban transformation experienced in the Land Walls Protection Area

\footnotetext{
The Septimus Severus Walls, the Constantinian Walls and a large part of the Anastasian Walls do not exist at the present.

2 Turnbull, 2004: 7-15.

3 İstanbul Site Management Directorate, 2011: 31-33.

4 "Historic Areas of Istanbul" was declared as a world heritage site by UNESCO on 06.12.1985 with the criteria (i), (ii), (iii) and (iv). The four
}

areas of the property are the Archaeological Park, at the tip of the Historic Peninsula; the Süleymaniye quarter with Süleymaniye Mosque complex, bazaars and vernacular settlement around it; the Zeyrek area of settlement around the Zeyrek Mosque (the former church of the Pantocrator), and the area along both sides of the Theodosian Land Walls including remains of the former Blachernae Palace.

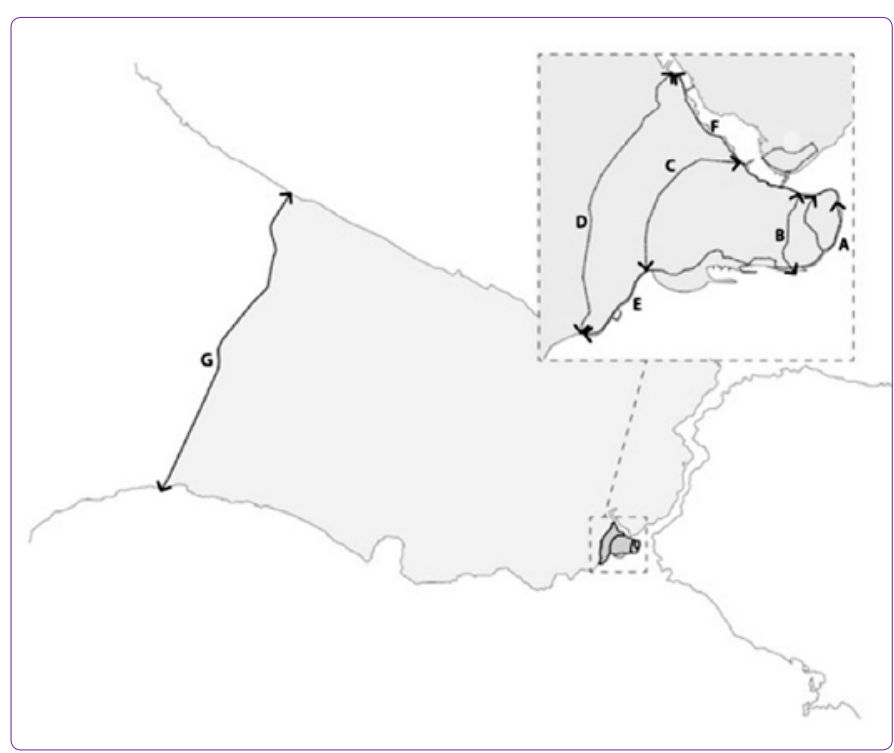

Figure 1. Schematic representation of the defence walls of the Historic Peninsula: (A) Byzas Walls, (B) Severus Walls, (C) Konstantin Walls, (D) Theodosius Walls, (E) Marmara Walls, (F) Golden Horn Walls, (G) Anastasius Walls (Prepared by Authors).

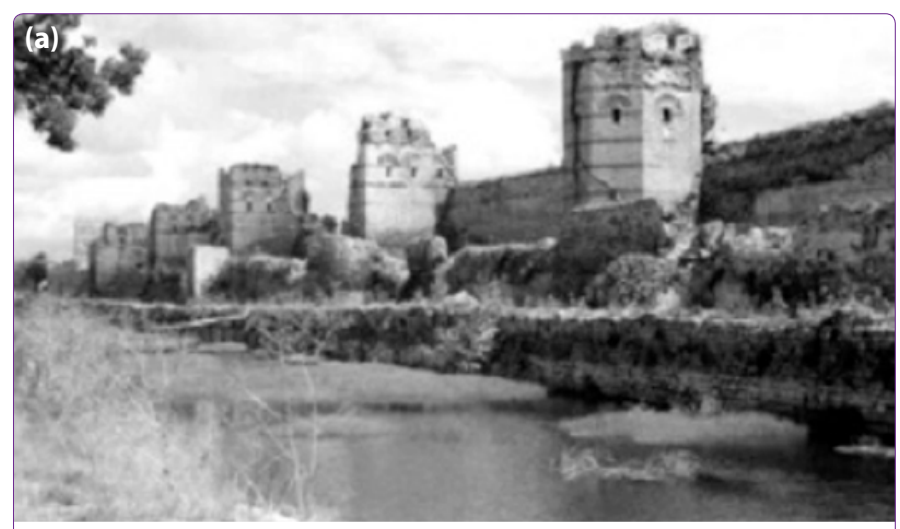

(b)

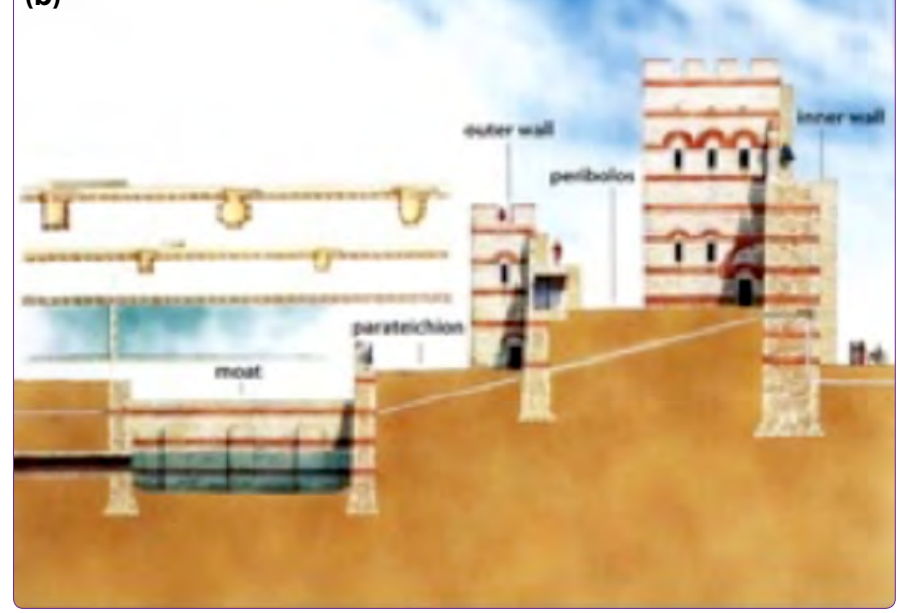

Figure 2. (a) An old picture from 1940s showing the Land Walls making up the inner wall, the outer wall and the moats, as well as the towers and the bastions located at different elevations (Turnbull, 2004: 12) (b) Cross-section and plan of the Land Walls (Turnbull, 2004: 11). 
Table 1. Chronological index and detailed information of six "Renewal Areas" identified within the "Land Walls Protection Area" under the Law No. 5366 (Istanbul Site Management Directorate, 2011: 54)

\begin{tabular}{|c|c|c|c|}
\hline$\#$ & $\begin{array}{l}\text { "Renewal Areas" identified under the } \\
\text { Law No. } 5366 \text { within the } \\
\text { Land Walls Protection Area }\end{array}$ & $\begin{array}{l}\text { Approval Date and Decision } \\
\text { Number of the Council of Ministers }\end{array}$ & $\begin{array}{l}\text { Official Gazette Publication } \\
\text { Date and Number }\end{array}$ \\
\hline \multirow[t]{2}{*}{1} & Neslişah and Hatice Sultan Neighbourhoods & $03.04 .2006-10299$ & $22.04 .2006-26147$ \\
\hline & & $13.09 .2006-10961$ & $13.10 .2006-26318$ \\
\hline 2 & Atik Mustafa Paşa Neighbourhood (Ayvansaray) & $03.04 .2006-10299$ & $22.04 .2006-26147$ \\
\hline 3 & Zeytinburnu City Walls Insulation Zone & $24.05 .2006-10502$ & $26.06 .2006-26207$ \\
\hline 4 & Beyazıt Ağa and Ereğli Neighbourhoods & 13.09.2006 - 10961 & $13.10 .2006-26318$ \\
\hline \multirow[t]{2}{*}{5} & Yedikule-Yenikapı $1^{\text {st }}$ Stage & 13.09.2006- 10961 & $13.10 .2006-26318$ \\
\hline & (Hacı Evhattin, İmrahor Illyasbey Neighbourhoods) & & \\
\hline 6 & $\begin{array}{l}\text { Veledi Karabaş, Cambaziye, Hacı Hamza, } \\
\text { Hacı Evhattin, İmrahor Illyasbey Neighbourhoods }\end{array}$ & $13.09 .2006-10961$ & $13.10 .2006-26318$ \\
\hline
\end{tabular}

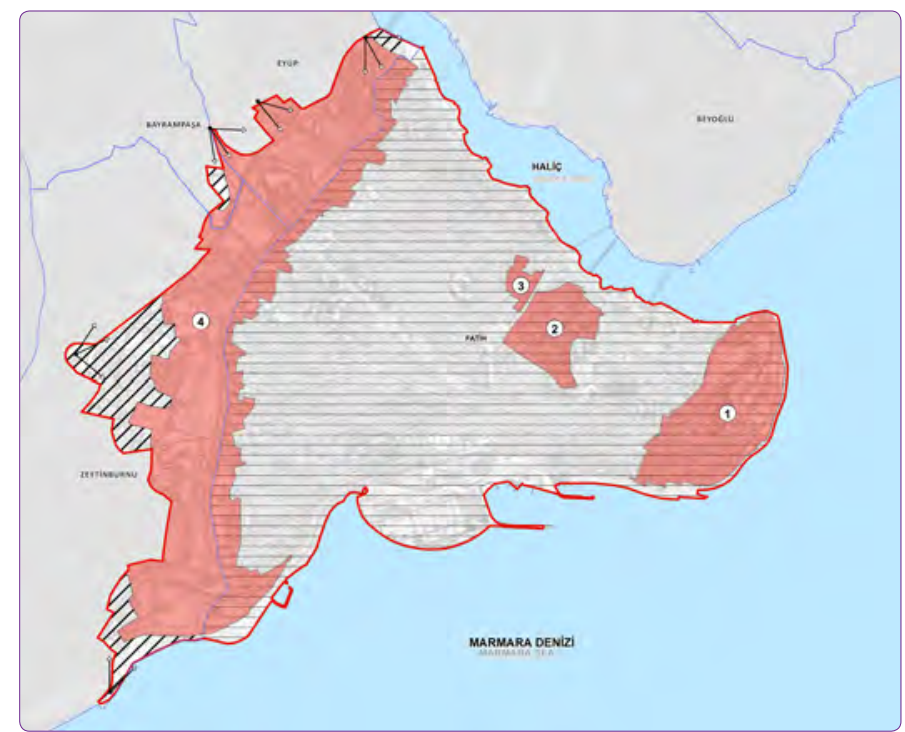

Figure 3. Four components of the 'Historic Areas of Istanbul World Heritage Site': (1) Sultanahmet Urban Archaeological Component Area of World Heritage Site, (2) Süleymaniye Mosque and Its Associated Component Area of World Heritage Site, (3) Zeyrek Mosque and Its Associated Component Area of World Heritage Site, (4) Istanbul Land Walls Component Area of World Heritage Site [URL-2].

from the perspective of the Law No. 5366 on "Conservation by Renovation and Use by Revitalization of the Deteriorated Historical and Cultural Immovable Property" [URL-3]. Mediating to declare "renewal areas" with rapid operations in qualified historical areas as of 2005 May $7^{\text {th }}$, the law became a tool to identify 15 so-called "time-worn" and "deteriorated" areas in the Historical Peninsula to be renovated. ${ }^{5}$ As it can be followed from Table 1, it is notable that six of these areas are located within the Land Walls Protection Area. As a matter of the fact, this paper evaluates the spatial effects of the "Renewal Law" through "Zeytinburnu City Walls

\footnotetext{
5 Köksal, 2007: 58-59 and İstanbul Site Management Directorate, 2011: 65.
}

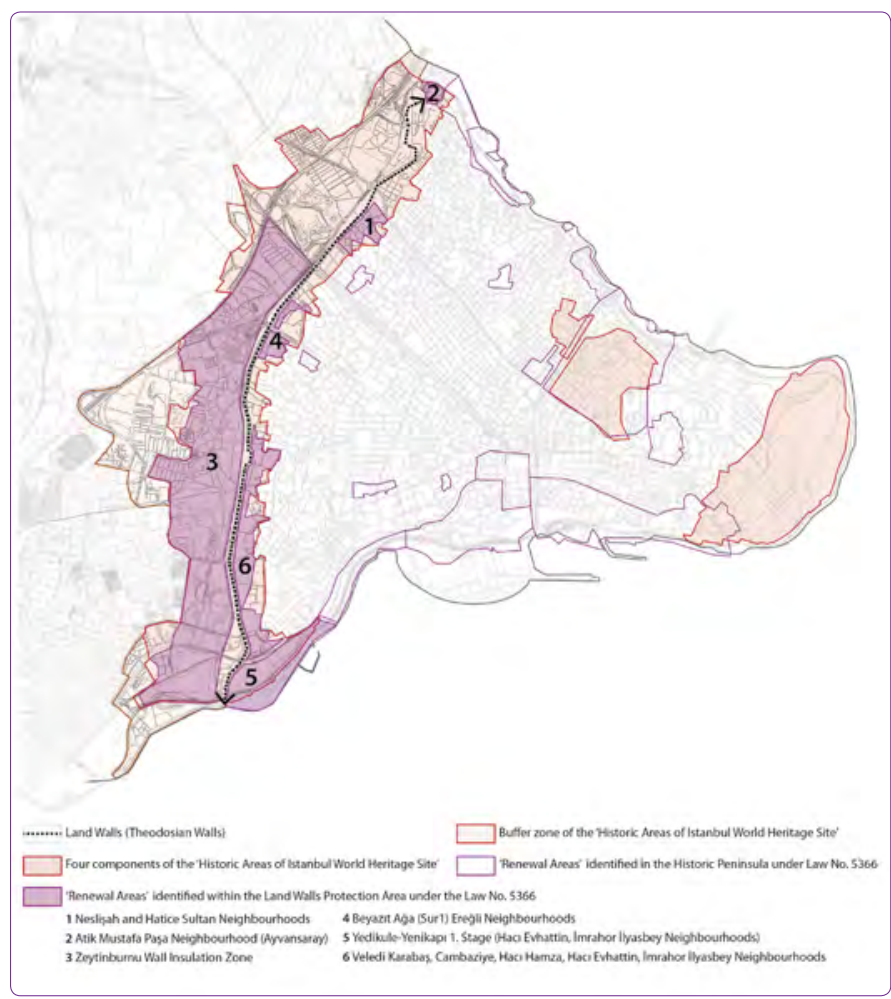

Figure 4. "Renewal Areas" identified under the Law No. 5366 within the borders of the Historical Peninsula and the "Land Walls Protection Area" superposed on the four components of the "Historic Areas of Istanbul World Heritage Site" (Prepared by Authors according to the information derived from Istanbul Site Management Directorate, 2011: 55).

Isolation Area", which is the largest among the six renewal zones determined within the Land Walls Protection Area and even the largest renewal area of Turkey, with its area of 250 hectares (Fig. 4). The renewal project entitled "Zeytinburnu Culture Valley" helps to reveal the spatial changes of the district as a renewal zone and evaluate the impacts of the Renewal Law No. 5366 on its $13^{\text {th }}$ year of force. 

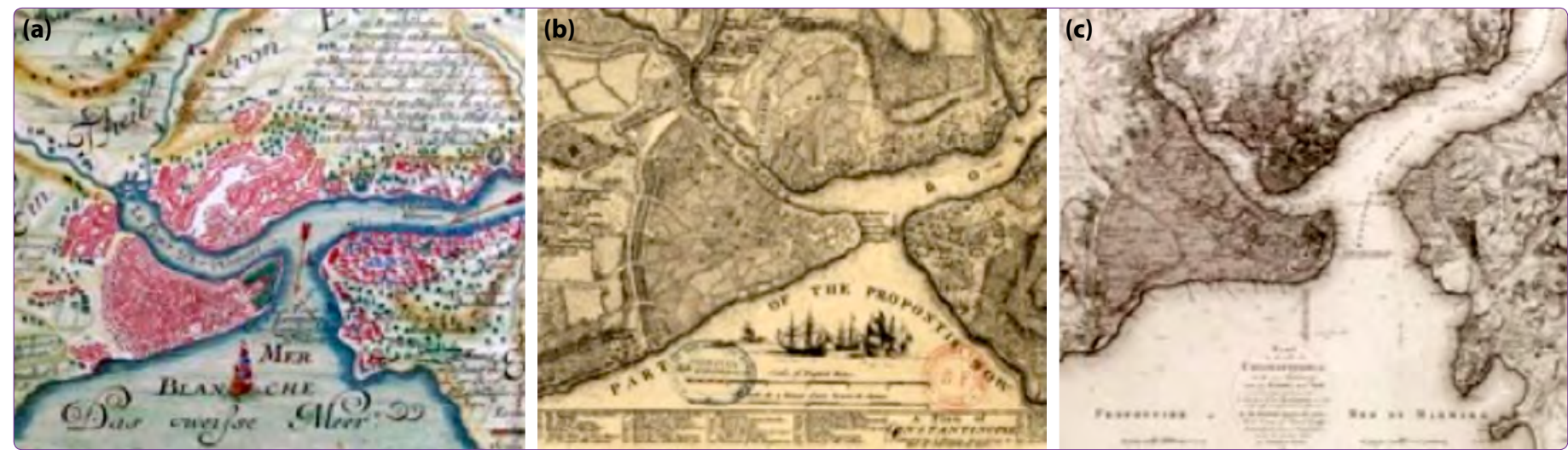

Figure 5. Old maps and gravures of Istanbul dated back to Ottoman Period, showing Zeytinburnu as one of the rare built-up areas located outside the city walls: (a) J. J. Andelfinger Map of Istanbul, 1735 (Yetişkin Kubilay, 2009: 90), (b) J. Rocque Gravure of Istanbul, 1742 [URL-5], (c) F. Kauffer Map of Istanbul, 1776 [URL-5].

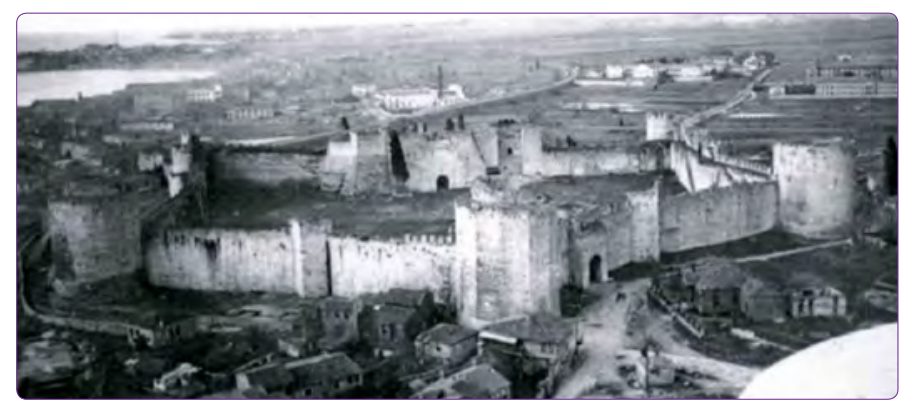

Figure 6. An old photo showing the initial configuration of the southern part of Zeytinburnu during the early 1900's (Başgelen, 2010: 21).

\section{A Brief Look At Zeytinburnu}

Zeytinburnu, located on the western side of the Historical Peninsula overlooking Marmara Sea, is an advantageous settlement area by its central location. Due to this spatial virtue, the history of Zeytinburnu, which is based on Roman Empire was progressed over the course of Byzantine, Ottoman and Turkish Republican Periods.

In detail, Zeytinburnu, in the name of "Strongylon", ${ }^{6}$ was an area untouched in the Roman and early Byzantine Periods. Located outside the city walls, it did not represent a crowded settlement until people living within the inner city decided to move outskirts due to their fear of devastating disasters. ${ }^{7}$ However, availability of information on a wide variety of special events such as coronation ceremonies, march pasts, military exercises, sports competitions, etc., which were held here, indicates that Zeytinburnu was an imperial and military zone during that period. ${ }^{8}$

During the Ottoman Empire Period, when a sharp differentiation was observed in the city as "inside" and "out-

\footnotetext{
Zeytinburnu was called as "Strongylon" in the Roman and Byzantine Periods. "Strongylon" was known to be an extension of "Hebdomon" (Bakırkoy), which meant "seventh milestone" because of its seven miles distance from the Million

Stone. Further information can be reached from Özbayoğlu, 2005: 12 and Akbulut, 2005: 188.

Özbayoğlu, 2005: 12-14 and Akbulut, 2005: 186-188.

Özbayoğlu, 2005: 14.
}

side" of the walls, Zeytinburnu was shaped through religious buildings belonging mostly to non-Muslim minorities or different Muslim cults, as they were not welcomed to live inside the walled city. ${ }^{9}$ On the other hand, this "outer world" was also equipped with a number of bigger-scale monumental structures throughout time. Belonging to the minority groups, these monuments including churches, monasteries, tombs, hospitals etc. such as Yenikapı Mevlevi Lodge, Balıklı Spring and Greek Hospital and Surp Pırgiç Armenian Hospital began to form the initial spatial configuration of the area [URL-4] (Figs. 5 and 6). ${ }^{10}$

As it can be seen from the old photographs of almost all of these structures underlined, the surrounding green areas stand out (Fig. 7). This situation, which can also be followed from the old maps of the same period, demonstrated Zeytinburnu as a green zone in comparison with the urbanized walled city. The components contributing to the formation of this wide green belt in Zeytinburnu were urban gardens, agricultural fields, grasslands, meadows and cemeteries such as Çırpıcı Grassland, Veliefendi Garden, Kozlu Graveyard, etc. ${ }^{11}$

Zeytinburnu experienced a remarkable expansion during the Late Ottoman Empire. Parallel to the attempted spread of the city beyond the west of the Land Walls, leather industry was also introduced as a new function for the "outside city" and was decided to be located in Zeytinburnu due to its abundant water and underground resources..$^{12}$ Another sanction applied in this period was to place the low-income groups close to the labour-intensive leather production units in order to meet the labour shortage. Indeed, the beginning of industry-focus state of

\footnotetext{
Ortaylı, 2005: 88.

${ }^{10}$ Although not much in number, it is also known that some structures such as Merkezfendi Mosque and Seyitnizam Mosque were also built for the worship of Muslim people to Zeytinburnu due to the nearby
}

Muslim cemeteries. Further information can be reached from Özvar, 2005: 42-44.

Özvar, 2005: 44-52

Özvar, 2005: 54-55, Akbulut, 2005: 186-188 and Akçay, 1974: 303-331. 


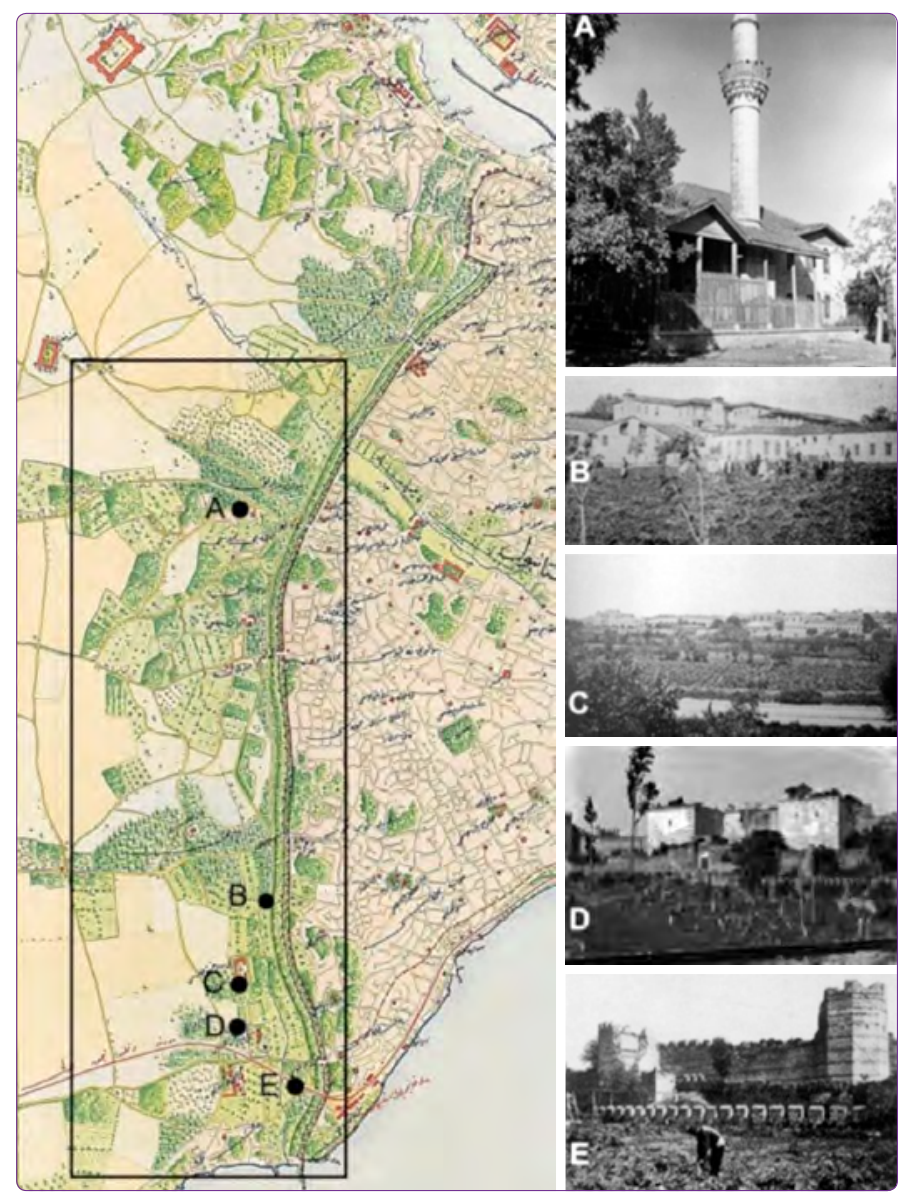

Figure 7. The green belt around the Land Walls and Zeytinburnu (Left) C. Stolpe Map of Istanbul, 1863 [URL-5], (A) Takkeci İbrahim Çavuş Mosque in 1910s [URL-6], (B) Surp Pırgiç Armenian Hospital in 1830s [URL-7], (C) Balikli Greek Hospital in 1834 [URL-8], (D) Cemeteries around the Porta Aurea during 1900s (Zeytinburnu Municipality Archive), (E) Urban Gardens of Zeytinburnu along Land Walls during 1920s [URL-9].

Zeytinburnu can easily be understand from the following narration of Evliya Çelebi's "Seyahatname"13 dated back to $17^{\text {th }}$ century; "...it is a small settlement consisting of a mosque, seven mescits ${ }^{14}$, one inn, one Turkish bath, seven fountains, three dervish lodges, three hundred leather processing tanneries and fifty adhesive ateliers". ${ }^{15}$

Thereafter, the proclamation of the Republic in 1923 in Ankara, the new capital of the state, caused almost entire Istanbul to remain on the background until 1930's. The new context of the city also affected Zeytinburnu and caused the district to experience an uncontrolled industrial growth. This situation also triggered the emergence of illegal "squatter" settlement areas in Zeytinburnu (Fig. 8)..$^{16}$ In order to solve these non-controllable problems underlined, a "modernization" effort was initiated. Among these modernization

\footnotetext{
13 'Seyahatname' is the travel book of ${ }^{15}$ Evliya Çelebi, 2014: 391.

Evliya Çelebi.

${ }^{14}$ Mescit means 'prayer room'.
}

efforts, which were carried out with the contribution of foreign planners and architects, the "Master Plan of Istanbul" prepared in 1937 by Henri Prost designated a 500-meterwide recreational belt along the Land Walls (Fig. 9). ${ }^{17} \mathrm{How}-$ ever, suchlike this proposal, most of the planning decisions proposed during this time period could not be realized due to the rapid growth rate of the city, high costs of the projects and/or private ownership patterns in the region. ${ }^{18}$

The on-going urbanization under the mentioned conditions escalated even more by the second half of the $20^{\text {th }}$ century. In this period of time, the multi-faceted breakthrough for becoming a part of the global world started a new era within the urban context of Istanbul with a strong emphasis on "urbanization". ${ }^{19}$ Indeed, Zeytinburnu and its environs were labelled as "heavy industrial area" in almost all of the plans that were prepared to find a solution to this growing urbanization problem. ${ }^{20}$ Yet, the interventions that supported the illegal development of the region once again became catalysts that exacerbate the problematic land-use. ${ }^{21}$

This transformation, which was initiated with Menderes Operations in 1950s, caused radical and sudden changes in 1960s. Due to new urban transportation decisions of Menderes Operations, carried out in the name of modernization policies, the typical green belt that could be observed along the Land Walls was destroyed. Particularly, construction of Vatan and Millet Boulevards, the new roads spanning the in east-west direction, affected the holistic structure of the Land Walls in a negative manner. Such that the pedestrian oriented transportation ended and some of the gates on the Land Walls, which were not wide enough for vehicle transition, were partially demolished. These destructions became a medium for the settlement area of Istanbul, which was once restricted to the boundaries of the Historical Peninsula, to expand westwards through Zeytinburnu.

As a result of this rapid growth to the west of the Land Walls, the population of Zeytinburnu that was 17,585 in the 1955 census increased fivefold to 88,341 in only five years, ${ }^{22}$ the housing shortage was attempted to be resolved in the peripheries and the macro-form of the city became unidentifiable losing its long-lasting characteristics. ${ }^{23} \mathrm{As}$ this

\footnotetext{
17 Bilsel, 2010: 115-121, Tekeli, 2013 147 and Duranay et al. 1972: 76.

${ }^{18}$ Duranay et al. 1972: 76-79.

${ }^{19}$ Dinçer, 2011: 43-45.

20 This decision, which was firstly realized with the plan named as "Instructions for Industrial Areas of Istanbul" of 1947, then appeared in subsequent plans such as "Master Plan of Istanbul's Industrial Zones" of 1955 and "Istanbul Industrial Estate Plan" of 1966. Further information can be reached from Duranay et al. 1972: 80-109.

${ }^{21}$ Akçay, 1974: 12-15.

${ }^{22}$ Population of Zeytinburnu kept gro-
}

wing since then. Indeed, the population of the region in 1990, 2000 and 2017 censuses were 165,679; 247,669 and 287,378 , respectively. Further information can be reached from www.tuik.gov.tr.

In this era, the rapid urbanization transformed the 'industrial society' into the 'information world', the 'fordist production' into the 'flexible production', the 'nation state' into the 'globalized world', the 'world of modernist minds' into the 'world of postmodern mentalities'. Further information on this transkeli, 2013: 4-5. formation can be reached from Te- 

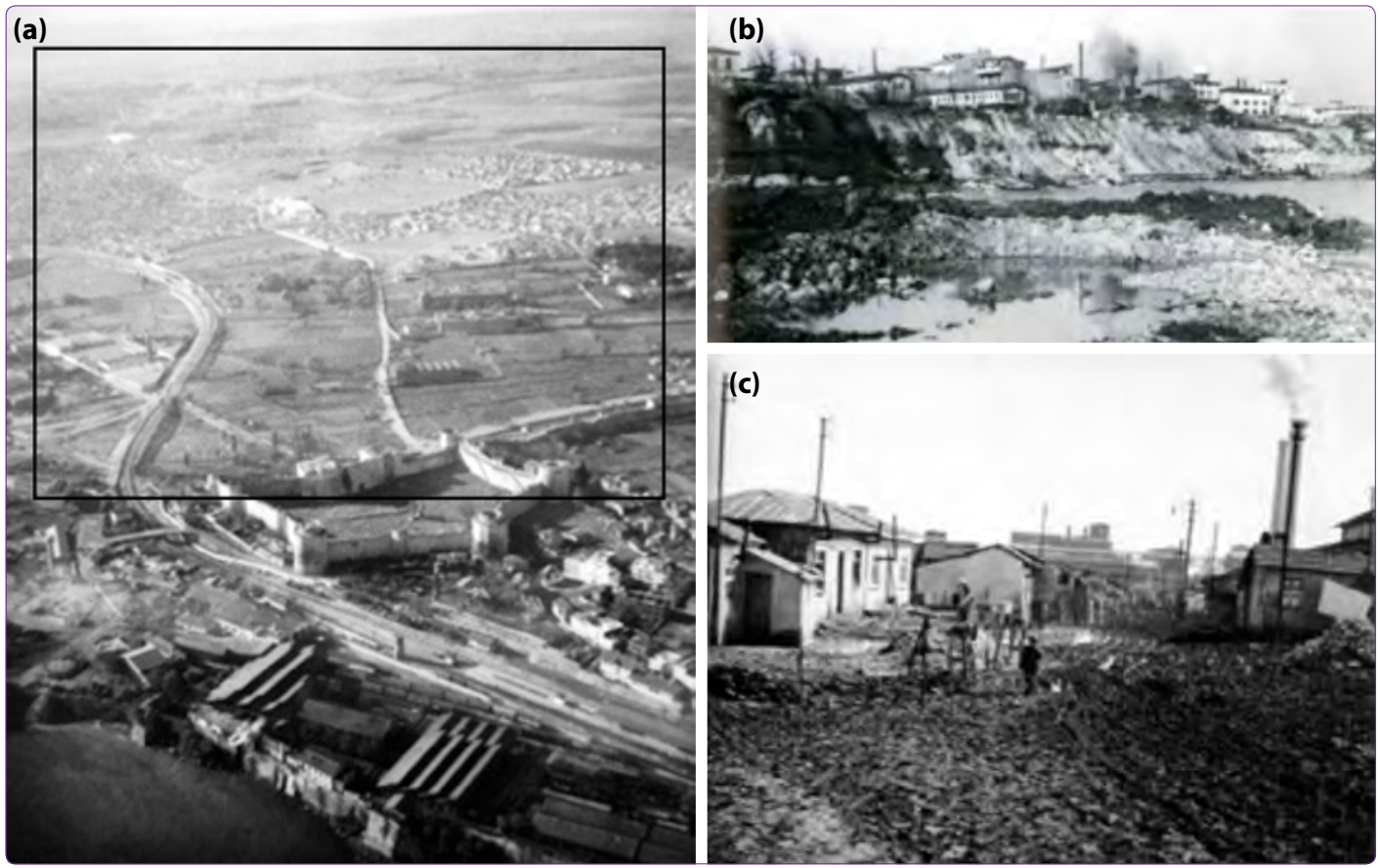

Figure 8. (a) An old photograph of Zeytinburnu dated back to 1940s, depicting the growing urbanization; the industrial area on the left and the illegal housing towards the back (Yelmen, 2005: 75) (b) Industrial growth in Zeytinburnu during 1930s (Yelmen, 2005: 73), (c) Squatter settlement areas of Zeytinburnu during 1940s [URL-9].

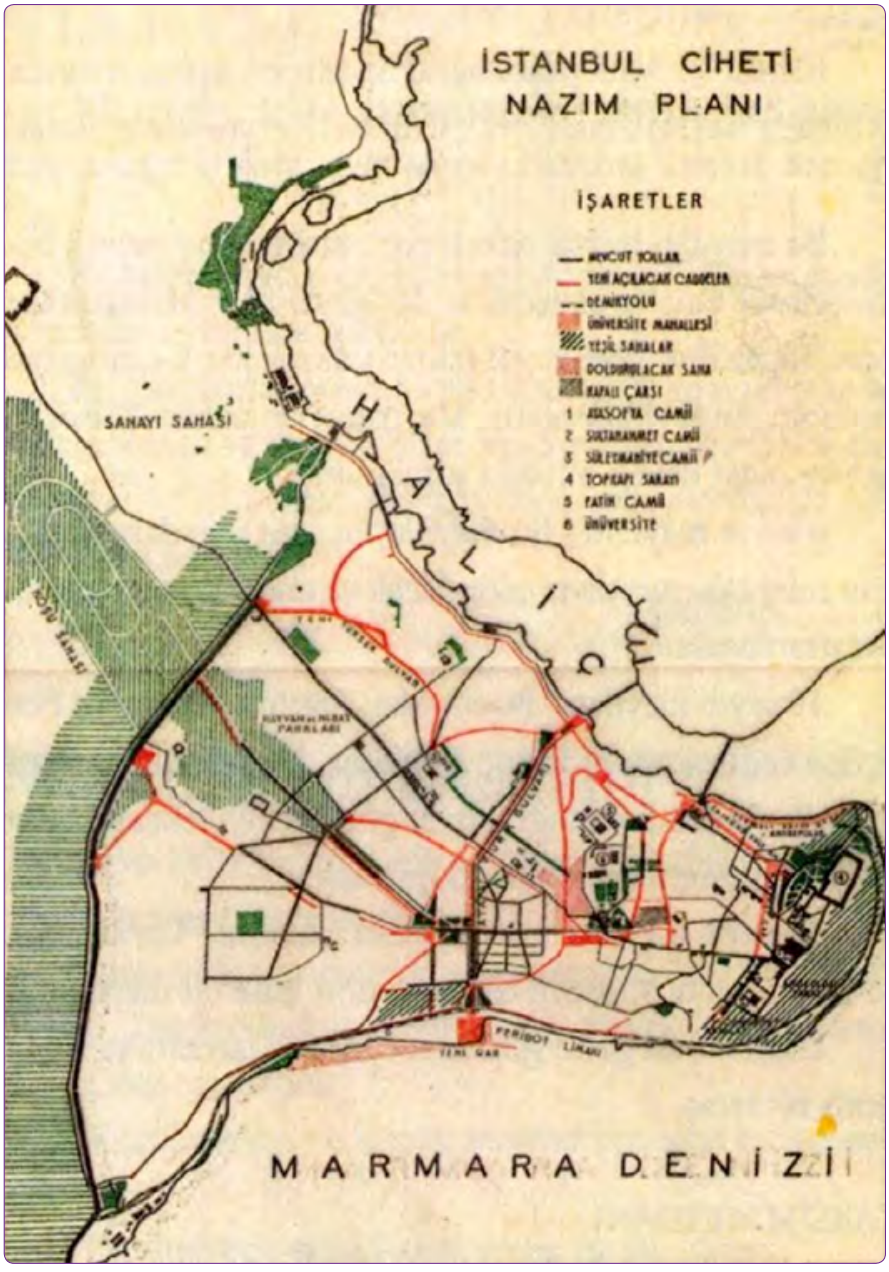

Figure 9. The "Master Plan of Istanbul" prepared in 1937 by Henri Prost, showing the 500-meter-wide recreational green belt proposal (Atatürk Library Archive) uncontrollable growth did not receive much attention from the stakeholders, the irrepressible urban transformation, taking place throughout Istanbul has also manifested itself in centrally located Land Walls Protection Area as well. In consequence of short-term plans that are no longer practically applicable to the ever-changing conditions of the city, some incompatible uses continued to emerge around the Land Walls in an uncontrollable manner. ${ }^{24}$ Consequentially, the area remained neglected and became one of the places where undesirable activities took place. ${ }^{25}$ This situation that damages the precious identity of the region, caused the surroundings of the Land Walls to remain in the spotlight due to the urban rent they generated. ${ }^{26}$

The "Istanbul Historical Peninsula Master Plan" of 1964 thankfully broke this dilemma. Based on this Master Plan, which brought the previous plans together, Prost's green band was identified as a conservation zone called "City Walls Isolation Area". ${ }^{27}$ Nonetheless, this conservation-oriented initiation was discarded again in 1970s. In accordance with the decision of "Great Istanbul Master Plan" prepared in 1971, Zeytinburnu was proposed to become a new transfer centre. Parallel to this recommendation, a port was built on the shore and an intercity bus terminal was constructed in Topkapı. However, because of the traffic congestion created by the inadequate infrastructure of the terminal, it did not take long for decision makers to relocate it for assigning new uses to this particular area of Zeytinburnu. ${ }^{28}$ Another

\footnotetext{
${ }^{24}$ Yelmen, 2005: 58-60 and Dinçer, 2011: 47.

${ }^{25}$ Altan and Güler, 2013: 19-35 and Ortaylı, 2005: 89.

${ }^{26}$ Ahunbay, 2007: 66.

27 "City Walls Isolation Area" is a kind

of conservation area, which is protected through a set of special principles.

${ }^{28}$ These decisions were taken on the basis of Zeytinburnu Maltepe Master Plan of 1994.
} 

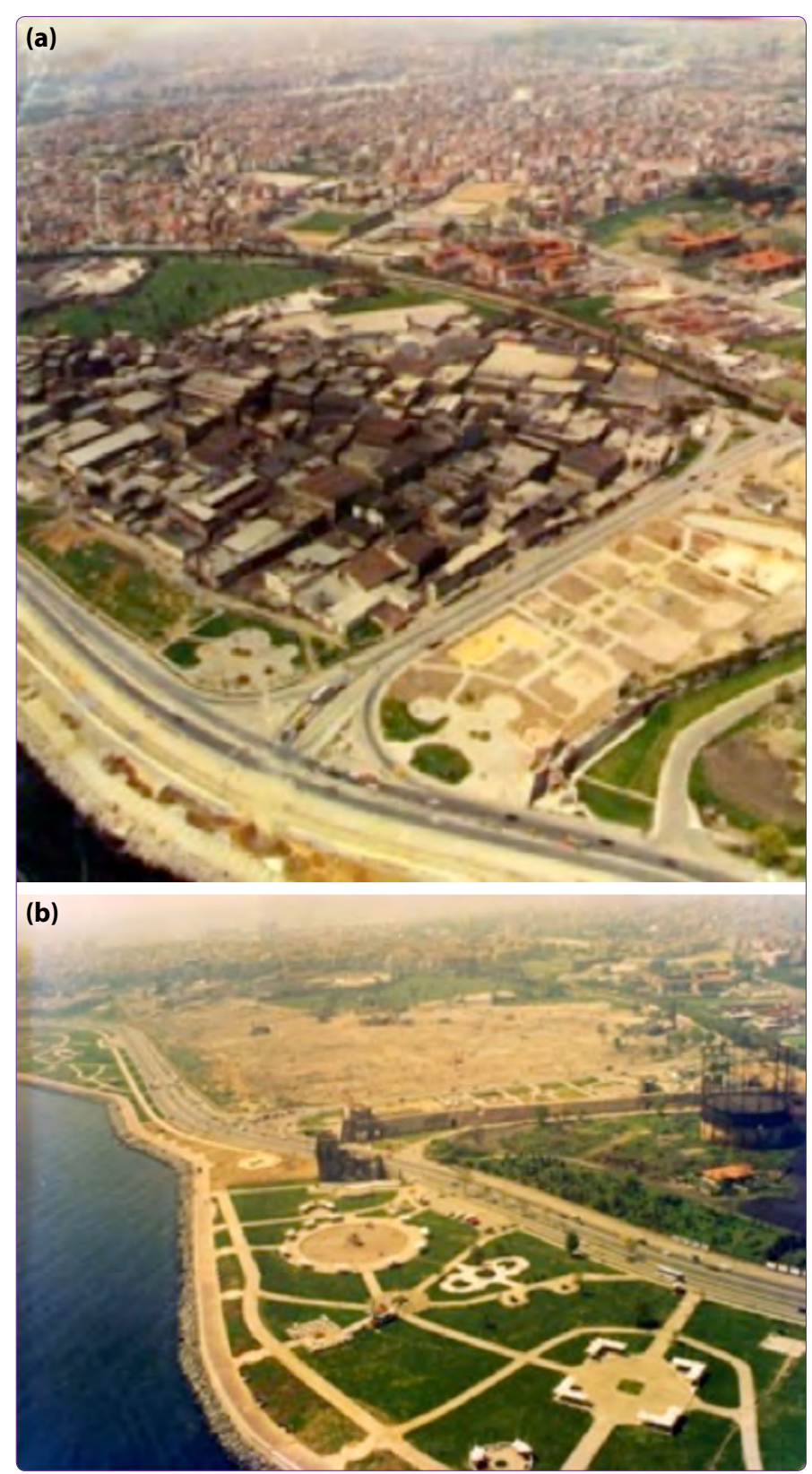

Figure 10. (a) The leather industry in Kazlıçeşme, 1980s [URL-9], (b) The vacant parcels after the relocation, late 1990s [URL-9].

major change observed in the region took place in the industrial sector. In order to rehabilitate the close vicinity of the Land Walls as well as to take advantage of the increased urban rent of the area, the leather industry that existed in the district for many years was relocated. ${ }^{29}$ Thereafter, all the structures were demolished and the vacant parcels remained neglected for years (Fig. 10).

Following such an adverse progression, "Land Walls Zoning Plan" was prepared for the city walls and their immediate surroundings in 1981, during the UNESCO World Heritage List candidacy period of Istanbul. Within the con-

${ }^{29}$ Tekeli, 2013: 294 and Yelmen, 2005: 78.

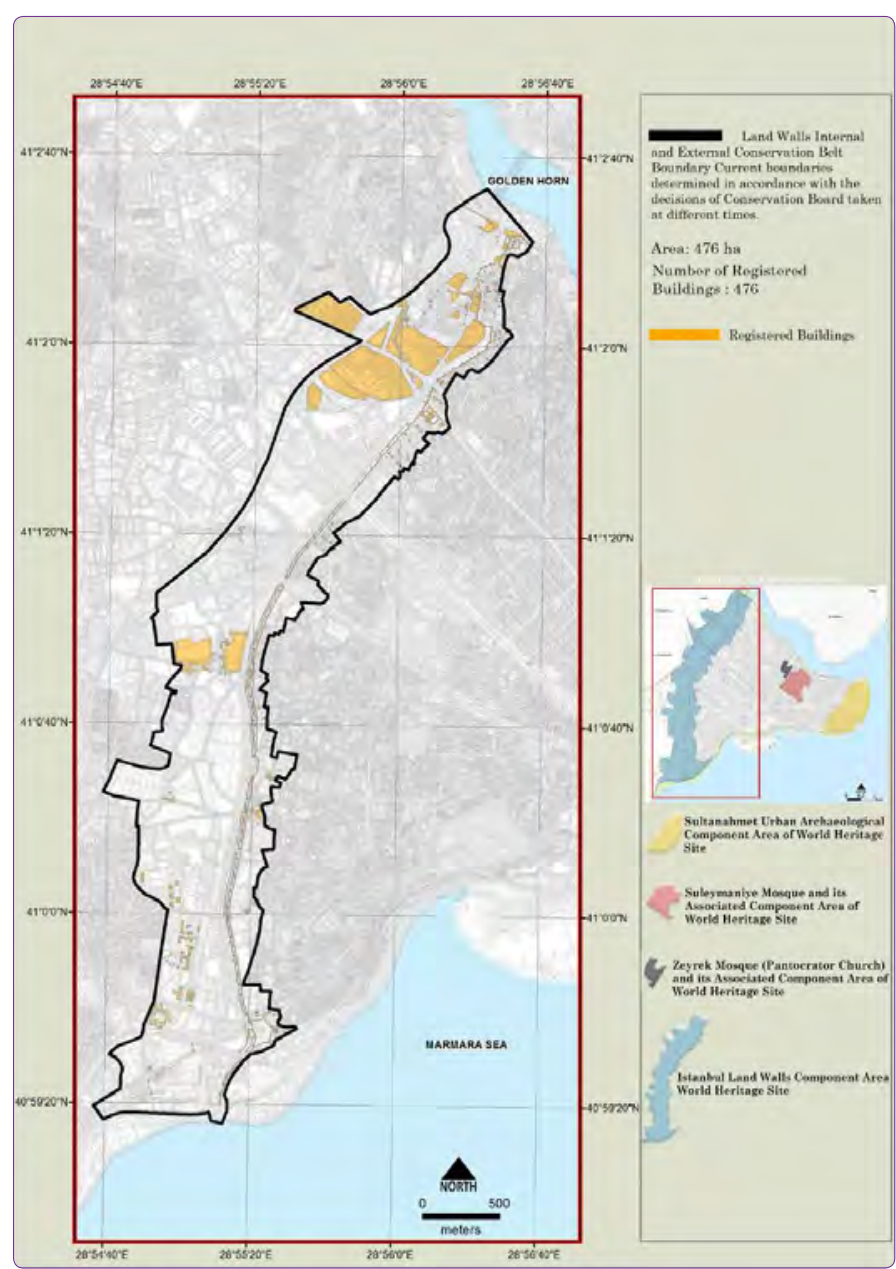

Figure 11. The boundaries of the "City Walls Insulation Area" identified in 1981 [URL-1].

tent of this plan, the exact boundary of the "City Walls Isolation Area" ${ }^{30}$ was identified and then the designated area was listed within the scope of the Law No. 2863 of July 21, 1983 on "Conservation of Cultural and Natural Property" [URL-10] (Fig. 11). Thereafter, as of 1985, following the identification of the site as one of the world heritage sites in Istanbul, the conservation of Zeytinburnu has become a global responsibility of both national and international institutions. This concern became a medium to put the abandoned "Land Walls Protection Area" on the agenda as a zone that needs urgent intervention. ${ }^{31}$

The Law No. 5366 and Its Spatial Effects on Zeytinburnu: 'Zeytinburnu Culture Valley Project' Although a large number of studies have been con-

${ }^{30}$ The exact boundary of the "City Walls Isolation Area" was approved on 19.06.1981, by the 12850 numbered decision of the Istanbul Board of Protection of Cultural and Natural Values (No. 1).

${ }^{31}$ The warning given by the UNESCO World Heritage Committee to remove the "Land Walls Protection Area" from the UNESCO's World Heritage List was also a catalyst in initiating this transformation process. Further information on this situation can be reached from the State of Conservation (SOC) Reports of UNESCO, http://whc.unesco.org/en/soc/3580. 
ducted to save the historical character of Zeytinburnu against the above-mentioned negative effects of urbanization; the renewal area entitled "Zeytinburnu City Walls Isolation Area", which was declared based on the Law No. 5366 on "Conservation by Renovation and Use by Revitalization of the Deteriorated Historical and Cultural Immovable Property" of 2005, can be defined as the basis of extensive changes in the socio-spatial identity of the district. Within the "borders of metropolitan municipalities with a population exceeding 50,000 ", local authorities as the main decision-makers are provided with extensive rights by the Law No. 5366, to intervene the "degenerated" conservation areas in order to realize their dreams of bringing back the glory of the district in its "good old days" [URL3] [URL-11]. In other words, the Law No. 5366 that allows to designate "conservation areas" larger than 1 hectare as "renewal areas" and allows to intervene them by removing the "deteriorated" traces of the past through so-called restoration, urban design and landscaping projects was thought to be a saviour for Zeytinburnu. ${ }^{32}$

In fact, in order to revive the extinct historic urban fabric according to its original, to promote the religious tourism by prioritizing historical potentials and to meet every kind of modern-day needs via contemporary designs; Zeytinburnu part of the "City Walls Isolation Area" was proclaimed as a "renewal area" in accordance with the Law No. 5366 in 2006. ${ }^{33}$ Then, the decisions of the Historic Peninsula conservation plans were overridden and the renewal area started to be managed by the Zeytinburnu Municipality Urbanism Atelier (ZESSAT) under the name of "Zeytinburnu Culture Valley Project" [URL-11 and URL-12]. ${ }^{34}$

In parallel to the aim underlined in the first article of the Law No. 5366, the main target of "Zeytinburnu Culture Valley Project", encompassing a number of listed buildings belonging to different periods, was identified as "to re-construct and restore the conservation areas registered and declared as conservation sites by the councils for conservation of cultural and natural property and their conservation zones, which are worn out and on the verge of losing their specificity" (Fig. 12) [URL-3]. In accordance with this purpose, an "Urgent Expropriation Decision" was taken by the Municipality of Zeytinburnu in order to prepare the project area soon for implementation. ${ }^{35}$ In response, "Zeytinburnu City Walls Isolation Area Conservation Master Plan" was prepared in 2007. Depending on the decisions taken in the Master Plan, the implementa-

\footnotetext{
32 Dinçer, 2011: 47-48 and Köksal, ${ }^{34}$ The idea of this kind of a project 2007: 61.

33 This decision was taken upon the 24.05.2006 dated 10502 numbered decision of Council of Ministers. It was then issued in 23.06.2006 dated Official Gazette.
}

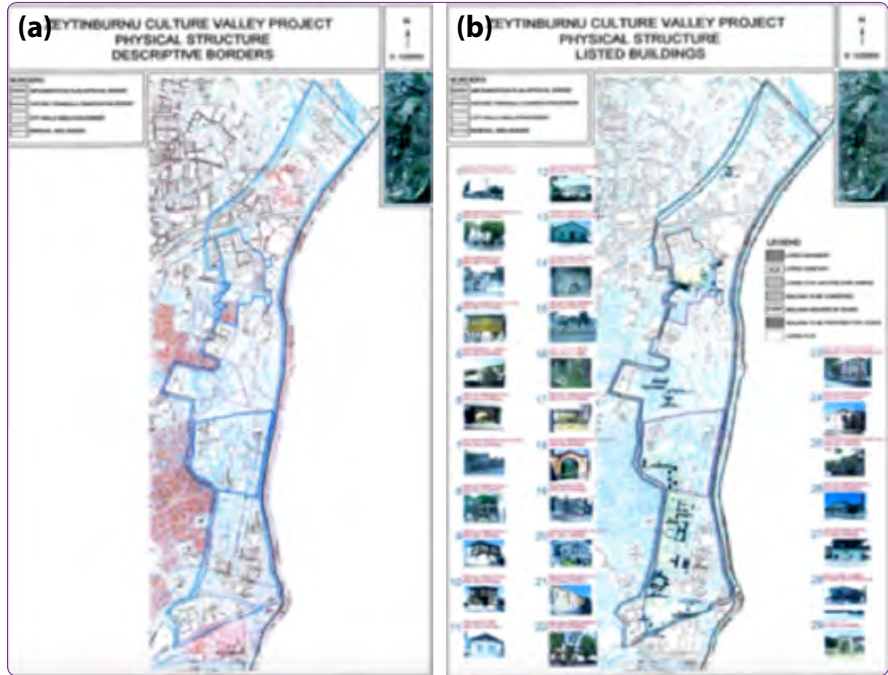

Figure 12. (a) Boundaries of 'Zeytinburnu Culture Valley Project' (Zeytinburnu Municipality Archive) (b) Listed buildings located within'Zeytinburnu Culture Valley Project' (Zeytinburnu Municipality Archive).

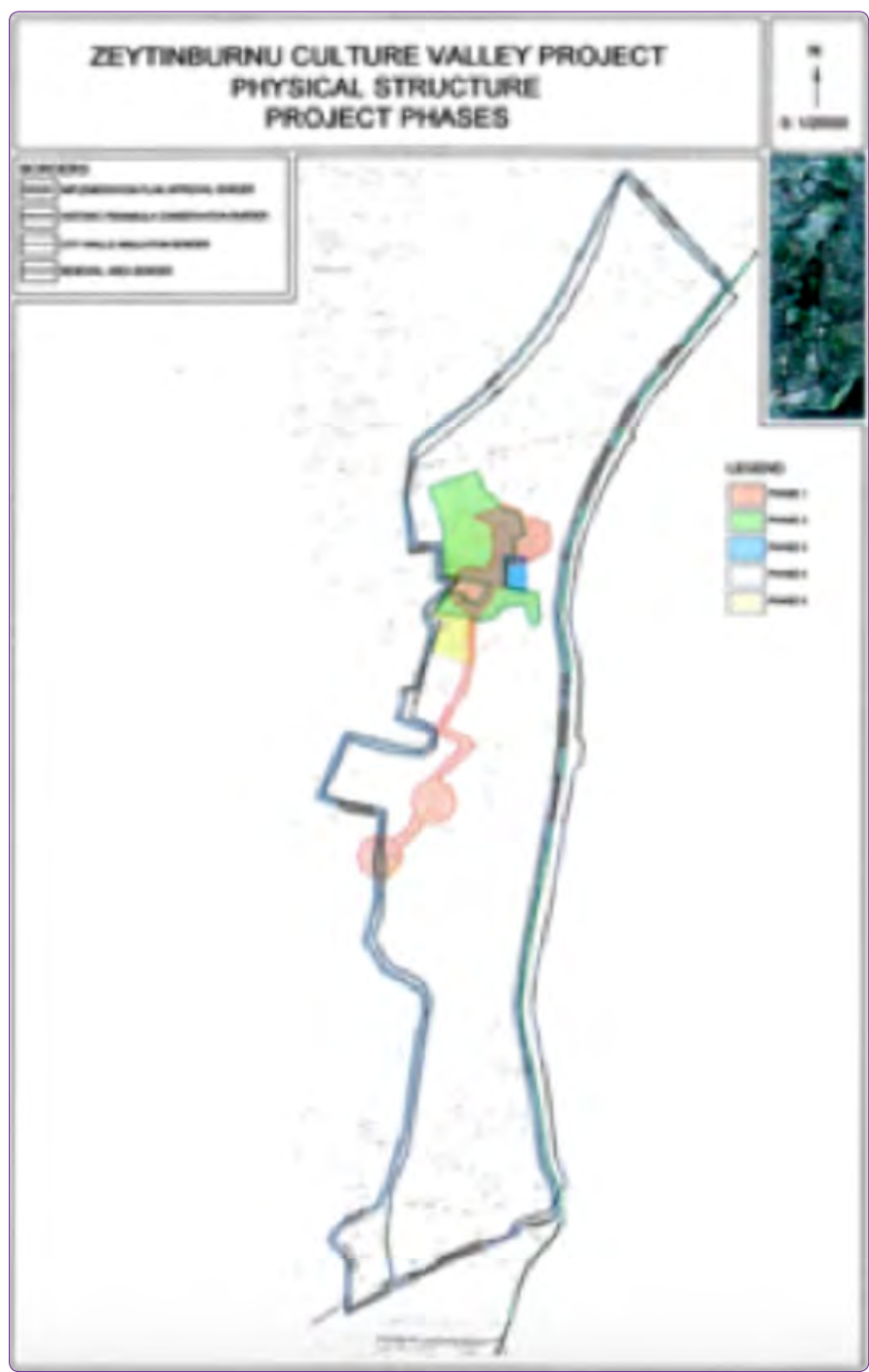

Figure 13. Diagram depicting the five stages of 'Zeytinburnu Culture Valley Project' (Zeytinburnu Municipality Archive). 
Table 2. Some examples of restoration, new design and landscaping works completed within the scope of the "Zeytinburnu Culture Valley Project", in alphabetical order [URL-12]

\begin{tabular}{|c|c|}
\hline Content of the Work & Projects \\
\hline Restoration & $\begin{array}{l}\text { - Abdulbaki Pasha Library } \\
\text { - Balıklı Square and Bakery Building } \\
\text { - Gate of Medical Plants Botanic Garden } \\
\text { - Hacıbaba Fountain } \\
\text { - Hacımahmut Ağa Small-Mosque } \\
\text { - Hamuşan and Mevli Dervish Lodge's } \\
\text { Fountain } \\
\text { - Kazlı Çeşme Fountain } \\
\text { - Kazlıçeşme Fatih Mosque } \\
\text { - Kazıçeşme Turkish Bath } \\
\text { - Merkezefendi Mosque } \\
\text { - Merkezefendi Turkish Bath } \\
\text { - Merkezefendi Harem Building } \\
\text { - Merzifonlu Kara Mustafa Pasha Mosque } \\
\text { - Seyitnizam Fountain } \\
\text { - Seyitnizam Mosque and Mausoleum } \\
\text { - Takkeci İbrahim Agha Mosque } \\
\text { - Yedikule Chest Hospital } \\
\text { - Yenikapı Mevlevi Dervish Lodge } \\
\text { - (...) }\end{array}$ \\
\hline New Design & $\begin{array}{l}\text { - Additional Building of Avrupa College } \\
\text { - Additional Building of Balıklı Greek } \\
\text { Hospital } \\
\text { - Additional Building of Yedikule Chest } \\
\text { Hospital } \\
\text { - Biruni University } \\
\text { - Cultural District of Turkish World } \\
\text { - High School of Mensucat Santral } \\
\text { - Panorama } 1453 \text { Conquest Museum } \\
\text { - Turkish Basketball Federation } \\
\text { - Zeytinburnu Semiha Şakir Nursing } \\
\text { Home } \\
\text { - (...) }\end{array}$ \\
\hline Landscaping & $\begin{array}{l}\text { - 700. Yıl Park } \\
\text { - Cultural Route Rehabilitation Project } \\
\text { - Medical Plants Botanic Garden } \\
\text { - Merkezefendi Park and Sports Field } \\
\text { - Merkezefendi Square } \\
\text { - Mevlevihane Square } \\
\text { - Seyitnizam Mosque Front Square } \\
\text { - Topkapı Culture Park } \\
\text { - Turkish Park } \\
\text { - (...) }\end{array}$ \\
\hline
\end{tabular}

tion process of the "Zeytinburnu Culture Valley Project" was planned to be processed through five stages: 'Cultural Route Project', 'Topkapı Culture Park and its Environs', 'Ottoman Neighbourhood', 'Improvement of Housing, Tourism, Commerce and Social Areas' and 'New Develop-

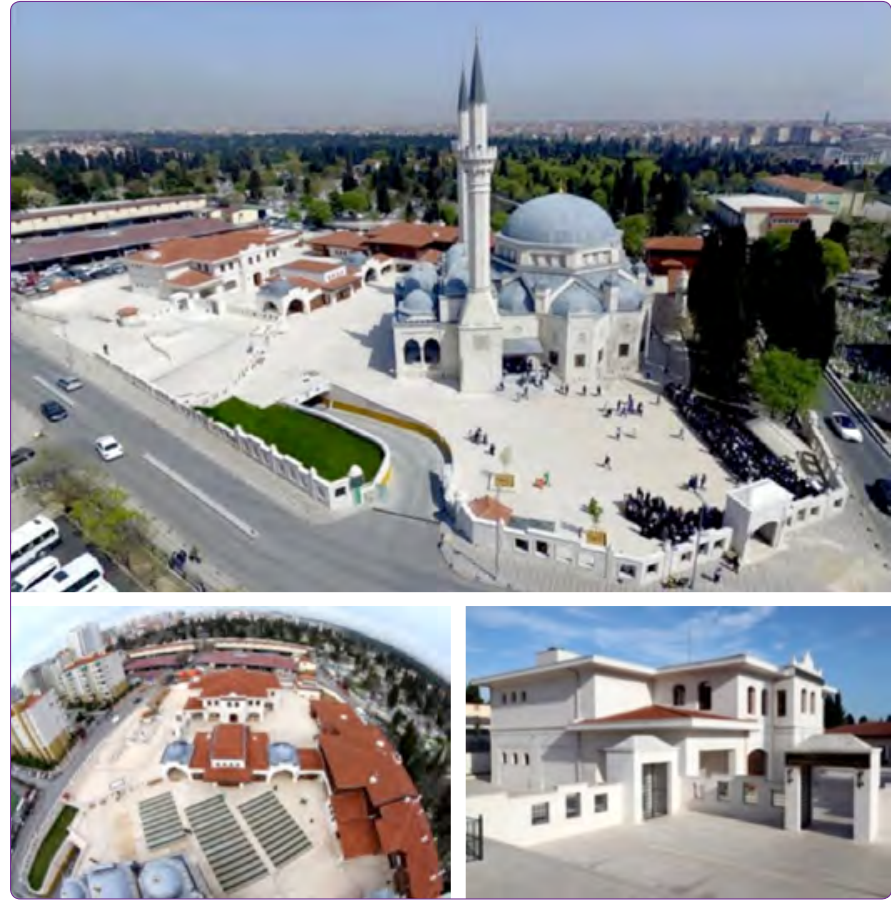

Figure 14. Post-project photographs of Seyitnizam Square, 2016 [URL-12].

ment Areas around Seyit Nizam Neighbourhood' [URL-12] (Fig. 13). ${ }^{36}$ Thereupon, within the scope of these stages listed, a number of restorations, new design projects and landscaping arrangements were realized (Table 2).

The renewal project was initiated with the "Cultural Route Project" phase. Connecting Merkezefendi Square, Yenikapı Mevlevîhâne and Seyitnizam Square, which are determined as the main focal points, the "Cultural Route Project" aimed to restore neglected historical assets and to develop projects related to housing, trade and education functions in the surrounding areas [URL-12] (Fig. 14).

The project was then continued with the second step named as the "Topkapı Culture Park" (Fig. 15). Planned after the relocation of Topkapı Bus Terminal, this stage was shaped around two newly built focal points. One of them is the "Panorama 1453 Conquest Museum" where Fatih Sultan Mehmet's conquest of Istanbul has been depicted (Fig. 16). The other one is the "Cultural District of Turkish World", which is a neighbourhood consisting of traditional house replicas of Turkic Republics (Fig. 17). ${ }^{37}$ In addition to these spots, info houses, children traffic training parks, restaurants and parking lots were also designed within this artificial greenery. This section of the "Zeytinburnu Culture

\footnotetext{
${ }^{36}$ The first stage was approved in 24.01.2007, the second and the third stages were approved in 31.10.2008, the fourth stage was approved in 30.07.2009 and the fifth stage was approved in 29.04.2010. Further information can be derived from Zeytinburnu Municipality.

${ }^{37}$ Traditional houses of Azerbaijan, Turkmenistan, Kazakhstan, Kyrgyzstan, Uzbekistan, TRNC, Tatarstan and Bashkortostan are being presented within Turkic Republic Neighbourhood.
} 


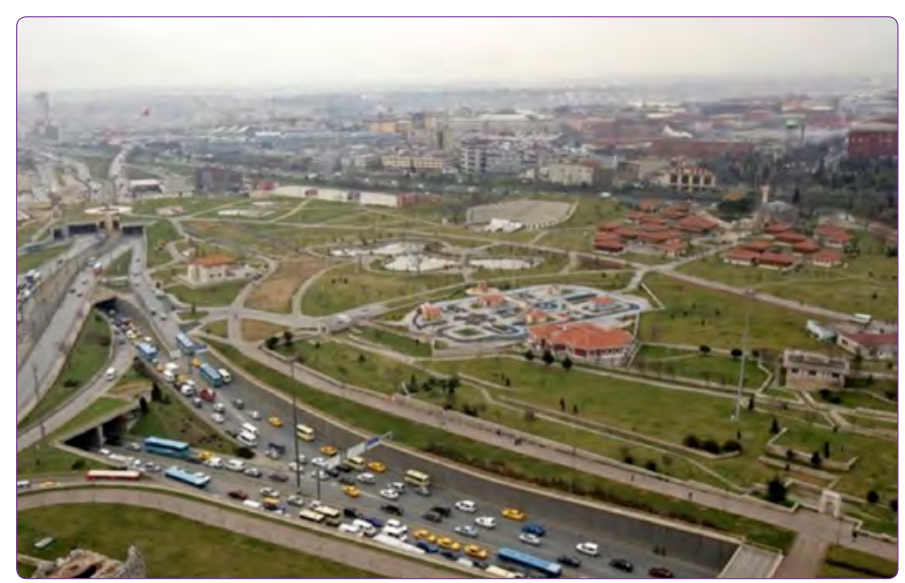

Figure 15. A general view of 'Topkapı Culture Park', 2017 [URL-2].

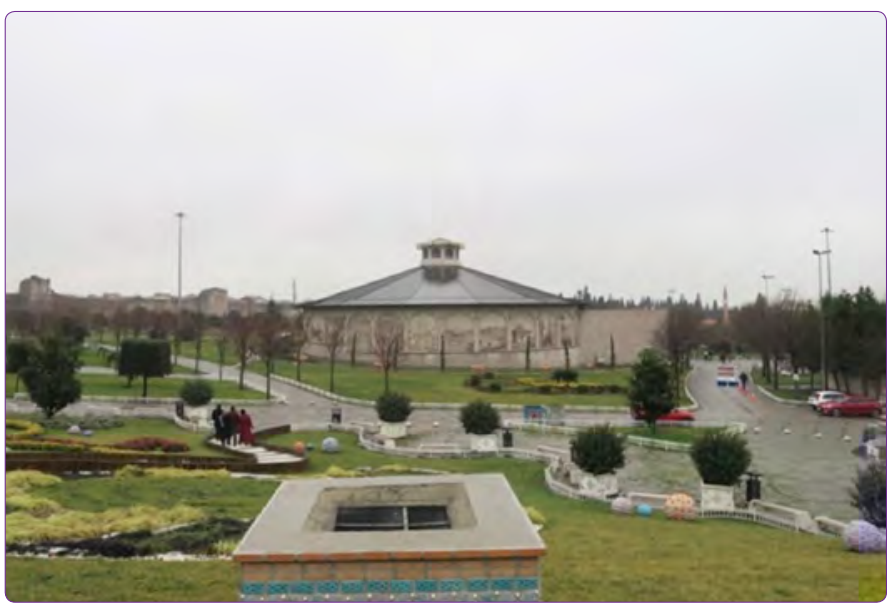

Figure 16. Panorama 1453 Conquest Museum, 2017 (Personal Archive of Authors).

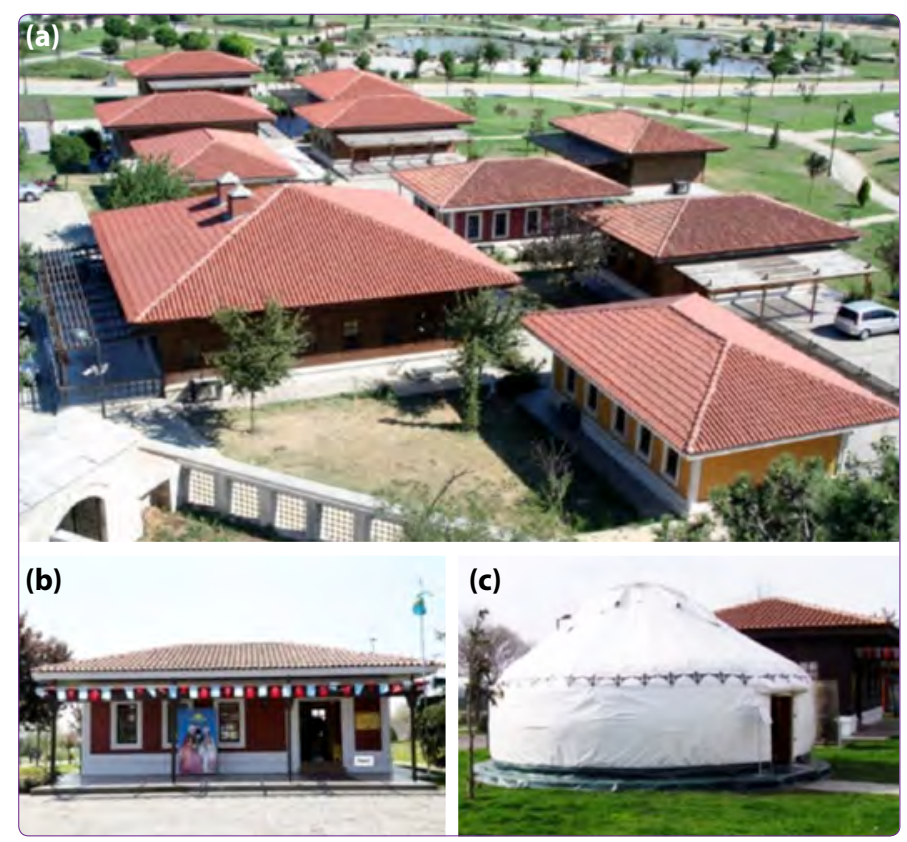

Figure 17. (a) A general view from the 'Cultural District of Turkish World', 2016 [URL-12], (b) Kazakhstan house, 2016 (Personal archive of Authors), (c) Kyrgyz tent, 2016 [URL-13].
Valley Project", which was projected to have an average of five thousand visitors per day, was considered as the new "tourism centre" of Istanbul [URL-11].

The third stage was realized in Merkezefendi Neighbourhood. This stage of the project was envisioned to be the "Ottoman Neighbourhood" of Istanbul. Being the pilot case of the "Zeytinburnu Culture Valley Project", the Ottoman Neighbourhood was presented a residential area containing 'pseudo-historic' new buildings (Fig. 18). Fictionalised with a "religious centre" scenario around the Merkezefendi Square, the third stage also included experimental yards called "Zeytinburnu Medicinal Plants Botanical Garden", which is the first active medical plant garden of Turkey, and "Turkish Garden", which was designed with the intent of presenting the typical 'Turkish style' landscaping elements [URL-12] (Figs. 19 and 20).

The fourth stage of the project, named as "Improvement of Housing, Tourism, Commerce and Social Areas", was designated to rehabilitate the entire project area. Within this phase, various restoration projects and new construc-
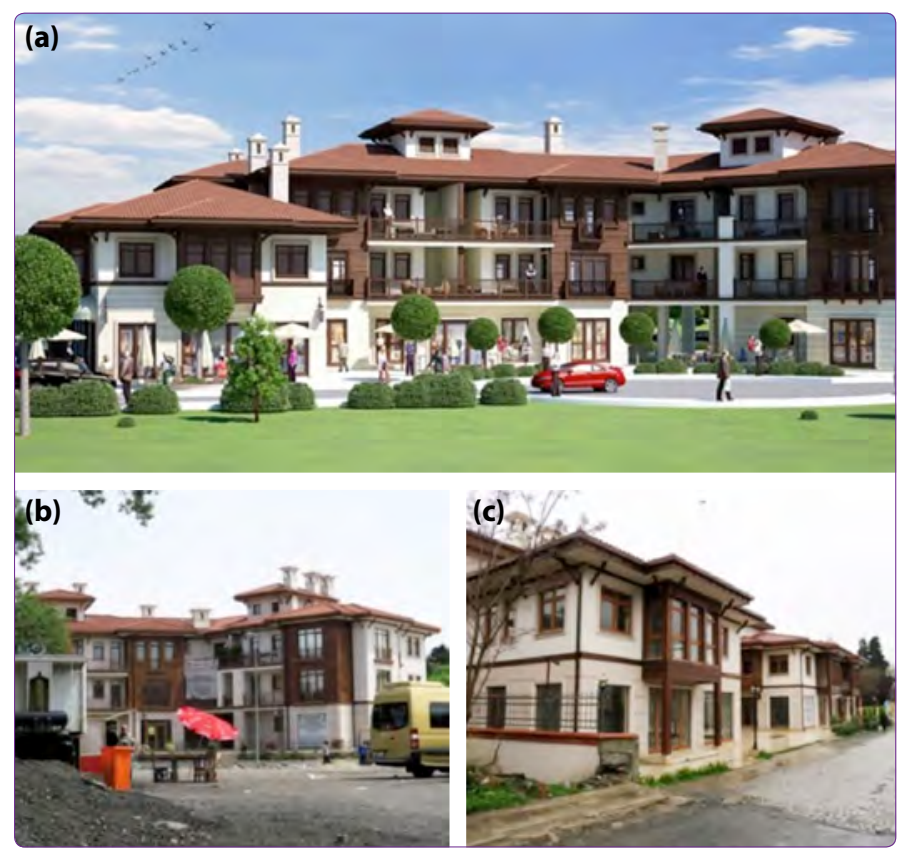

Figure 18. 'Ottoman Neighbourhood' (a) Render view of the project [URL-14], (b, c) Photos taken during construction, 2016 (Personal archive of Authors).

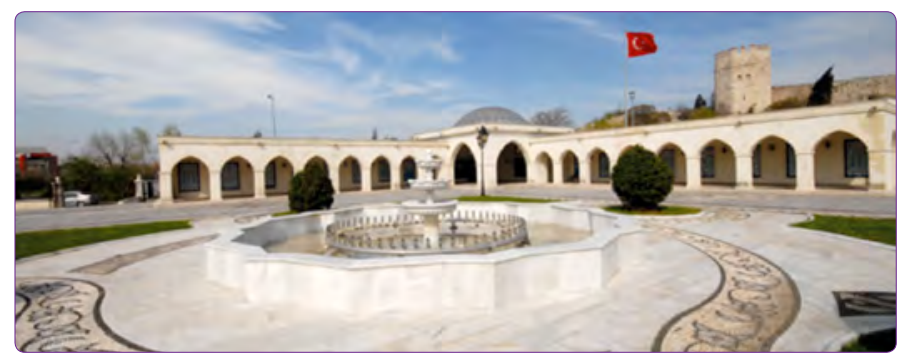

Figure 19. 'Turkish Garden', 2017 [URL-15]. 


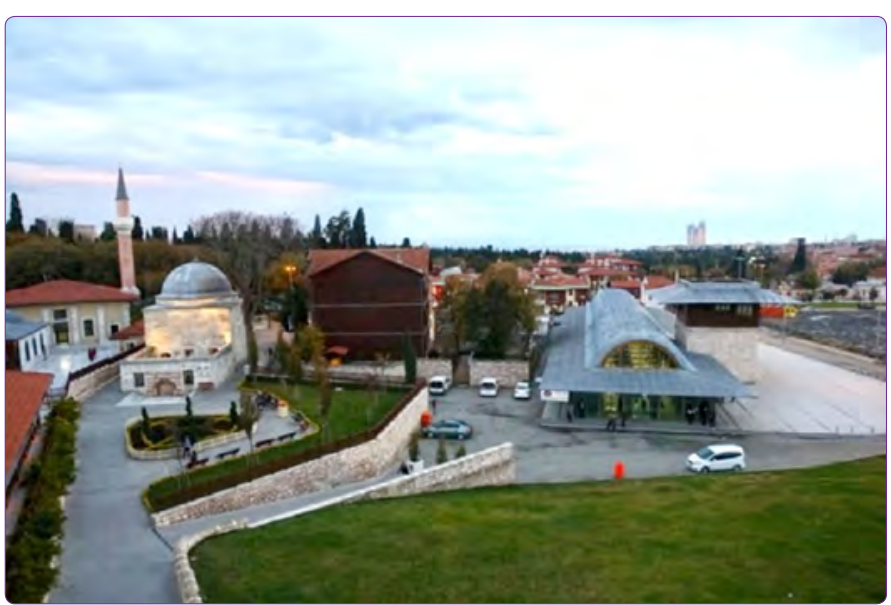

Figure 20. Post-project photographs of Merkezefendi Square 'religious centre', home to Merkezefendi Mosque on the left, Merkezefendi Mansion in the middle and Merkezefendi City Library on the right [URL-12].

tion works which are not appropriate with the historical identity of the district in terms of function, scale, appearance and/or conservation technique such as Merkezefendi Indoor Swimming Pool, Semiha Şakir Nursing Home, Merkezefendi Turkish Bath Restoration, Kazlıçeşme Square etc. were realized [URL-12] (Fig. 21).

Finally, the last intervention was made around Seyit Nizam section of the project area. This section, home to Church of St. Mary The Spring, was also considered as a tourist attraction point [URL-11]. In accordance with this tourism-focused idea, trade, tourism, urban services, health, education and religion were deemed suitable for the future use of the area.

In sum, when the "renewed" urban fabric of Zeytinburnu is investigated today, it can easily be observed that "Zeytinburnu Culture Valley Project" has threatening the long-lasting urban character of the district. Even, the project, which was said to meet the contemporary needs while respecting cultural heritage, stands as a constraint in managing the unique identity of the district.

One of the reasons causing this controversy is the $\mathbf{2 5 0}$ hectares size of the renewal project area. Although this extensive area once presented a rich urban tissue regarding scale, architectural style and function; the segmental approach caused the loss of the integrity of the district. The absence of any warning regarding such a large-scale project within the scope of the Historical Peninsula Management Plan completed in 2011 can be regarded as a significant indicator of this. ${ }^{38}$ The lack of definition of the criteria on the designation of renewal areas as well as the consideration of renewal projects in the law and its additional legal documents create another threat for the conservation and sustainability of historic urban fabric.

\footnotetext{
${ }^{38}$ İstanbul Site Management Directorate, 2011.
}

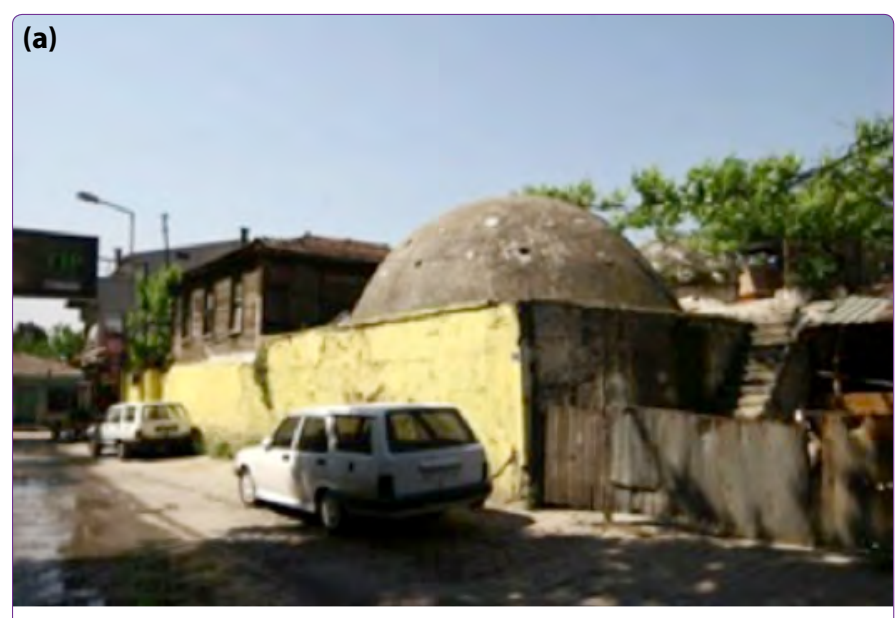

(b)

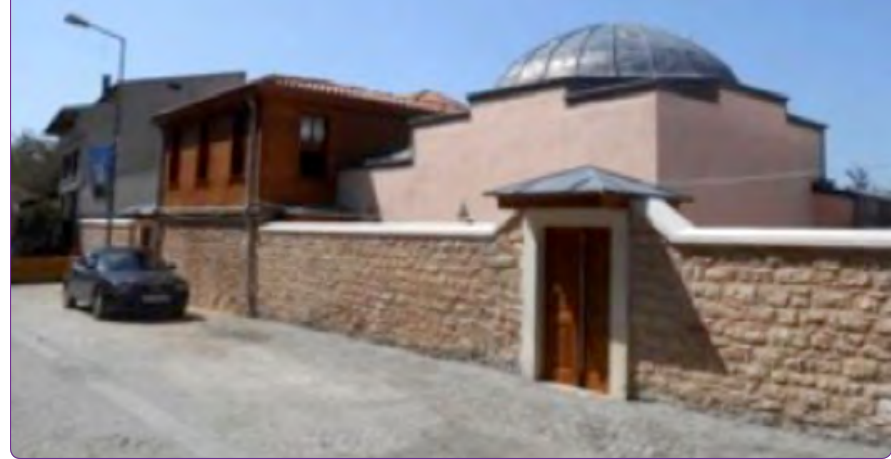

Figure 21. Merkezefedi Turkish Bath restoration; (a) Before restoration, 2007 [URL-16], (b) After restoration, 2017 (Personal archive of Authors).

Another reason causing this contrast is the reconstruction of a "fictional historic urban tissue". The renewal project allowed new functions and activities in order to revitalize and enrich the site, and this was mentioned as the key to the success of urban conservation. However, the inappropriate function selections that are not directly related with the history of the region affected Zeytinburnu negatively. Moreover, the use of similar architectural styles, material repetitions and imitations in recently built structures are incompatible with the heterogeneity of the urban tissue due to the historical stratification. Large-scale infrastructure investments have also supported this negative trend.

In addition to all these, the extensive deterioration, which depends mainly on the constant changes of plans regulated by the Law No. 5366, adds to this negative trend. The destruction of "Abdi Ipekci Sports Hall" that began recently in March 2018 to construct a bigger sport facility exemplifies this situation. "Istanbul City Museum" that is currently being built in the project area also signifies that the Renewal Law is still threatening the Land Walls Protection Area (Fig. 22). Further, as it can easily be followed 


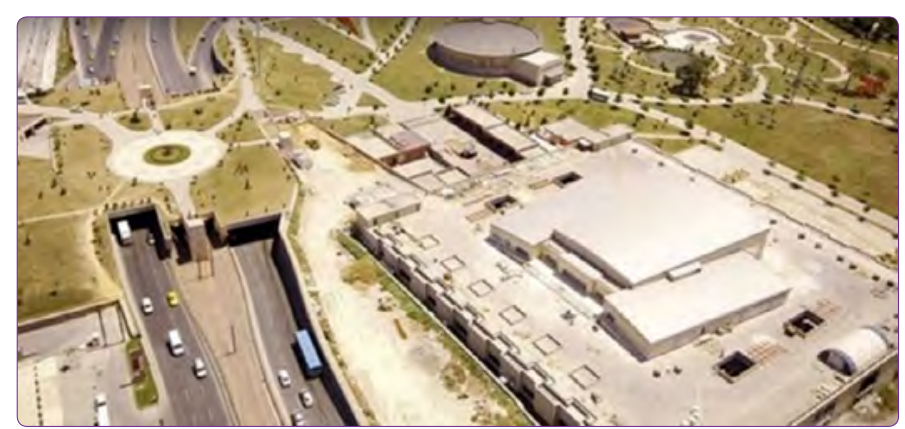

Figure 22. A view from the "Istanbul City Museum", being built in the renewal area at the present (Zeytinburnu Municipality Archive).
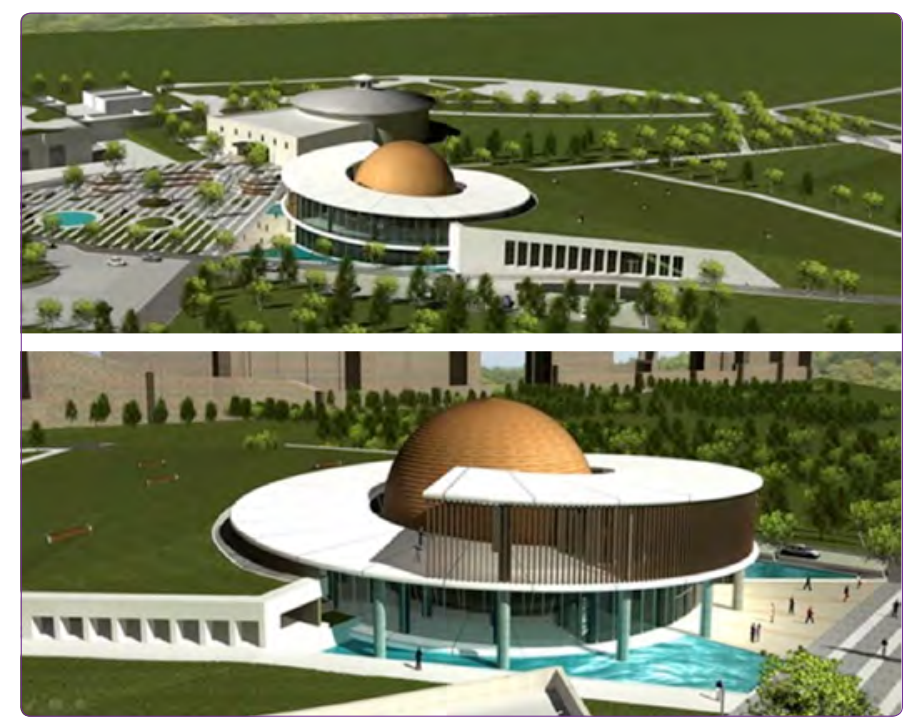

Figure 23. Render views of the "Planetarium" project [URL-17].

from the project renders of the "Planetarium", which will include exhibition lounges, multi-purpose halls, library and cafeteria, it is clear that no relationship is envisioned between the building and the world heritage setting (Fig. 23). Other upcoming projects, including biological pond, 4D cinematography centre, picnic area and ice-skating rink, have also raised concerns about the future of the area [URL-18].

\section{Discussion and Conclusion}

Zeytinburnu presents an example of a historically deeprooted area in Istanbul. Due to its religious, symbolic and natural character, it was once a settlement where different religions and sects lived together. But depending on the dramatic changes that took place in its land use pattern in a short period of time; the district turned into an undesirable destination of the city. "Zeytinburnu Culture Valley Project", having remained in the centre of the city, is one of the main sources of this spatial change generated around the close vicinity of the Land Walls.

"The residents of Zeytinburnu and the Istanbulites do not know the potential here. (...) We would like the people to take action with this project. We would like to take them
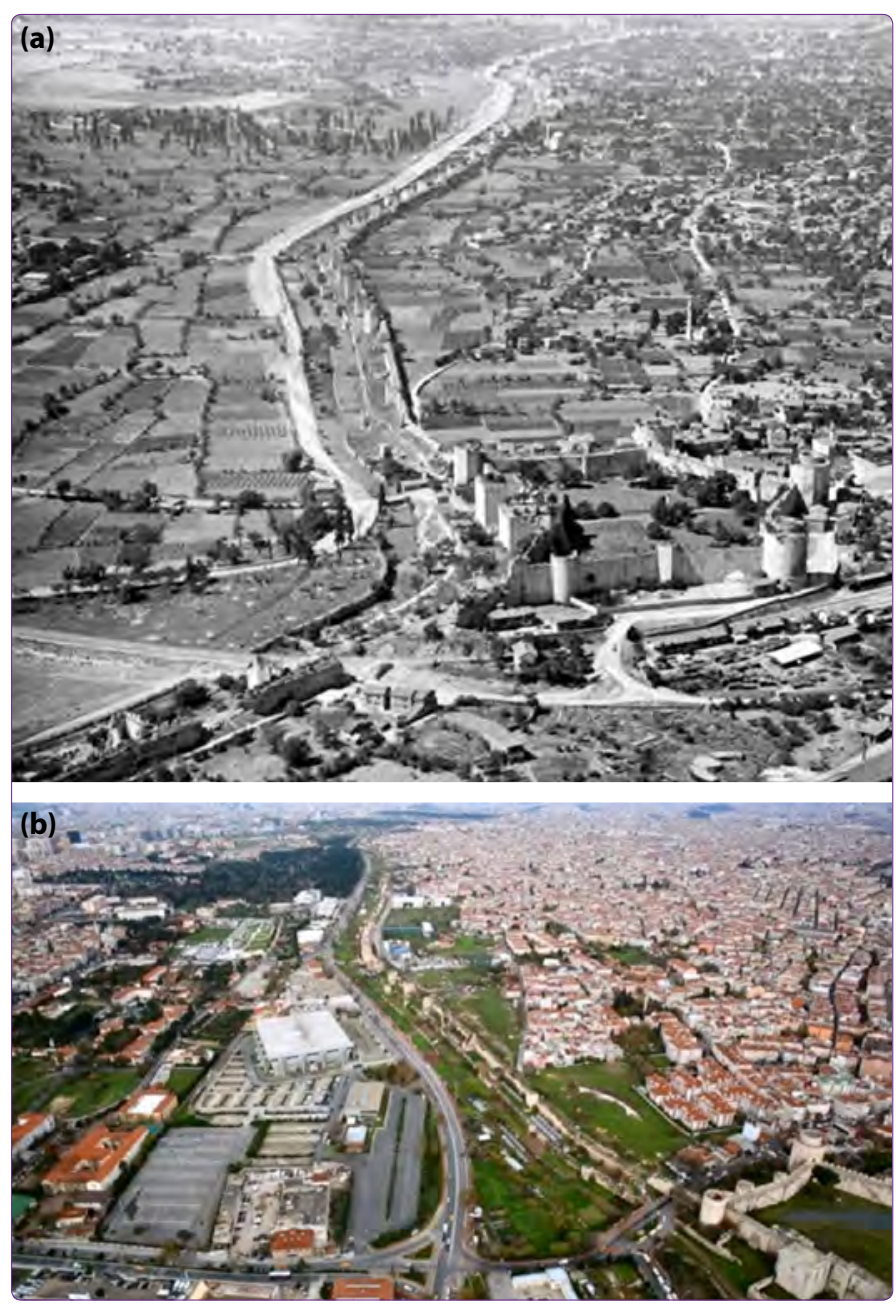

Figure 24. Zeytinburnu Culture Valley Project area from the same point of view (a) A view from 1940s [URL-9], (b) A view from 2017 [URL-2].

two or three thousand years ago to show them around the historical side of the district. We would like to have 24 hours activity in Zeytinburnu Culture Valley. We are searching for ways to benefit from the sea, the beach and the historical sites." [URL-11]. Undertaken with the cited announcement of Murat Aydın in 2006, the Mayor of Zeytinburnu Municipality, "Zeytinburnu Culture Valley Project" is a good example for evaluating the spatial outcomes of the Law No. 5366. As it can easily be followed from the slogan expressed by Aydın, "Zeytinburnu Culture Valley Project" aimed to eliminate the danger of losing cultural and historical values. However, as understood from the process, which lasted over ten years, the project that was implemented in the context of the Renewal Law has become an "obstacle" rather than a "tool" for the stated goal.

In fact, this situation is not just limited to "Zeytinburnu Culture Valley Project". The possibility of identifying renewal areas on historical urban fabrics, which are declared as protected areas under the Law No. 2863, has raised concerns about the conservation of cultural heritage in 


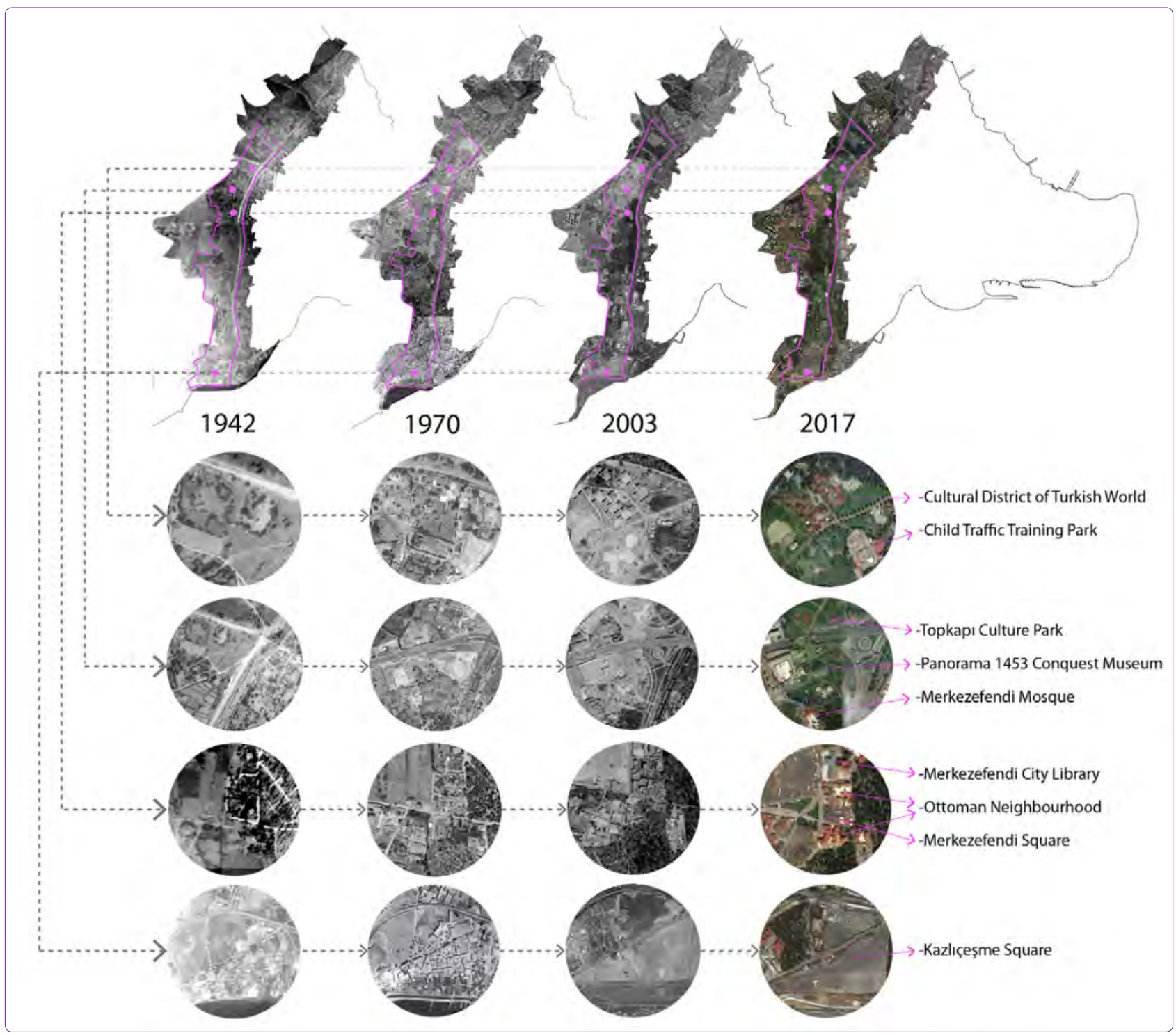

Figure 25. A general evaluation regarding the spatial effects of the Law No. 5366 with a number of spots from the "Zeytinburnu Culture Valley Project" through 1942, 1970, 2003 and 2017 aerial photographs (Prepared by Authors with the help of the aerial photographs derived from the Online Archive of the General Command of Mapping).

general. ${ }^{39}$ By attracting the attention of decision makers and by transforming heritage places to "objects" of urban transformation, the Law No. 5366 indeed tries to gather two opposite concepts "renewal" and "conservation" under a single title. Especially the fact that there is no reference to conservation plans in the Renewal Law has paved the way for the loss of qualified urban fabric by ignoring the side of conservation.

Introducing a recent legal measure as well as a new "urban trend" for Turkey ${ }^{40}$, the Law No. 5366 also directed local authorities, investors and developers to approach

${ }^{39}$ Dinçer, 2010: 25-27 and Köksal, 2007: 64

${ }^{40}$ There are 36 renewal areas in Turkey up to 2017 (Istanbul-23, Ankara-2, Karaman-2, Kütayha-1, Sam- sun-1, Kahramanmaraş-1, İzmir-1, Trabzon-1, Gaziantep-1, Antalya-1, Mersin-1, Afyon-1). Further information can be reached from: Özçakır et al. 2018: 12-13. cultural heritage for generating income and reinforcing political ideology. Above all, it appears that not only the national, but also the internationally accepted principles were not respected for renewal interventions. However, according to the $7^{\text {th }}$ Article of the law text, it is compulsory for the Law No. 5366 to comply with international conventions and recommendations [URL-3]. From this point of view, the base point of the Law No. 5366 totally contradicts the "Nairobi Recommendations" (1976), the "Washington Charter" (1987) and the "Valetta Principles" (2011), all of which are the texts aiming to express the conservational concerns of historical urban areas as well as to guide the contemporary architecture.

To illustrate; Article 3 of the "Nairobi Recommendations" emphasizes the importance of historical fabric as follows: 


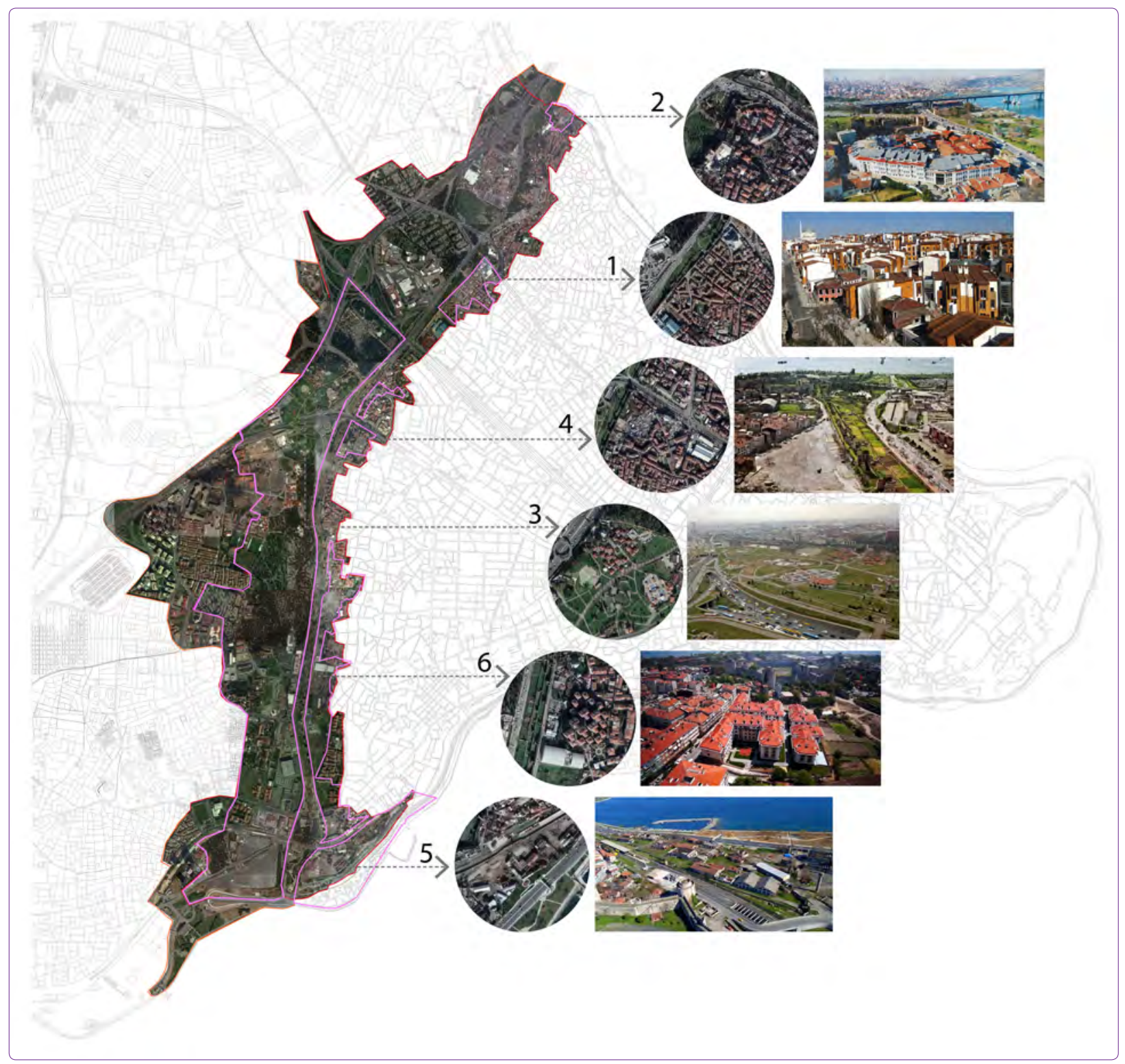

Figure 26. The "renewed" spatial configuration of the "Land Walls Protection Area", the numbers used to depict the renewal areas are associated with the ones given in Table 1 and Figure 4 (Prepared by Authors with the help of the 2017 aerial photograph derived from the Online Archive of the General Command of Mapping and photographs from URL-10 and URL-23).

"Every historic area and its surroundings should be considered in their totality as a coherent whole whose balance and specific nature depend on the fusion of the parts of which it is composed and which include human activities as much as the buildings, the spatial organization and the surroundings. All valid elements, including human activities, however modest, thus have a significance in relation to the whole which must not be disregarded." [URL-19].

Articles number 8 and number 10 of the "Washington Charter" underline new functions and activities attached to historic urban areas should ensure a compatible and harmonious relationship as a whole by saying "New functions and activities should be compatible with the character of the historic town or urban area." and "When it is necessary to construct new buildings or adapt existing ones, the existing spatial layout should be respected, especially in terms of scale and lot size."; respectively [URL-20].

Additionally, the article, stated under the heading of "Change and the Built Environment" of the "Valetta Principles", underlines the topic from the perspective of new design as; "New architecture must be consistent with the spatial organization of the historic area and respectful of its traditional morphology while at the same time being a valid expression of the architectural trends of its time and place. Regardless of style and expression, all new architecture should avoid the negative effects of drastic or excessive contrasts and of fragmentation and interruptions in the continuity of the urban fabric and space." [URL-21]. 
In conclusion, "new" expectations weaved into "old" living spaces in line with contemporary needs form the future. In this respect, historical urban areas, particularly the ones including world heritage sites, deserve to be treated with much greater care and expertise. Unfortunately, contrary to this, "Land Walls Protection Area" of Istanbul's Historical Peninsula is captured like a hostage in the hands of the "rapidly changing monster" 41 called the Law No. 5366 on "Conservation by Renovation and Use by Revitalization of the Deteriorated Historical and Cultural Immovable Property". ${ }^{42}$

Zeytinburnu Culture Valley Project as an example based on this "Renewal Law" justified the spatial concerns of adopting "renewal" action in protected areas without corresponding to the decisions set in international platforms. Although public awareness could not have been drawn much in comparison to other renewal projects realized in the Historical Peninsula, the project that is still in progress has created a new appearance for the "Land Walls Protection Area" (Figs. 24 and 25). Indeed, the incompatibility of scales and sizes of independent projects turned this precious region into an area of "opportunity" in which the broader strategy of physical regeneration took place.

As indispensable disciplines, it is practically impossible to distinguish "conservation" from "law" and "political economy". ${ }^{43}$ The Law No. 5366 that is still applicable for so-called "time-worn" and "deteriorated" conservation areas has indeed fed the "monster" as it has paved the way by identifying new renewal areas legally. In fact, UNESCO World Heritage Committee gave a warning on this topic in its "World Heritage Centre and ICOMOS Joint Reactive Monitoring Mission Report" entitled report of 2012 by saying: "Renewal areas under the Law No. 5366, as currently interpreted and implemented, appear to be escalating the problem rather than facilitating a solution. Urban renewal needs to be replaced by urban conservation, with work taking place in smaller packages, focused on in-situ repair of historic buildings. It needs to be accompanied by a diversity of infill buildings to a common but not overprescriptive brief, to avoid the areas becoming dominated by a single form and style of faux-traditional new building" [URL-22] (Fig. 26).

In parallel with this statement of UNESCO as well as the renewed appearance of the "Land Walls Protection Area", an integrated protection approach based on appropriate interventions, which are supported with contemporary architecture respecting the context of the historical area, expected to be formulated for Zeytinburnu case. As creating "new" opportunities necessitates the preservation of the "old", this process was further expected to achieve a deli-

\footnotetext{
${ }^{41}$ Ahunbay, 2007: 68. $\quad{ }^{42}$ Dinçer, 2011: 50-52. $\quad{ }^{43}$ Özçakır et al. 2018.
}

cate balance between conservation and renewal by keeping the existing potentials of the bigger picture in mind with the help of a group of experts. Nonetheless, some questions still remain to be answered: Why a protection site would like to be renewed? While the "new" grows rapidly, how can the consciousness on the valuable "old" be raised? How can the dilemma between "conserving" vs. "renewing" be resolved?

\section{References}

Ahunbay, Z. (2007) "Tarihi İstanbul ve Koruma Kurullarından Koparılan Yenileme Alanları", Mimar.ist, No: 26, pp.65-68.

Akbulut, M.R. (2005) "Zeytinburnu'nda Mekansal Dönüşüm", Ed.: Burçak Evren, Surların Öte Yanı Zeytinburnu, İstanbul, Zeytinburnu Belediyesi Kültür Yayınları, pp.186-209.

Akçay, F. (1974) Zeytinburnu: Gerçek Yönleriyle Bir Gecekondu Kenti, Çelikcilt Matbaası, İstanbul.

Altan, Ç. and Güler, A. (2013) Al İşte İstanbul, Yapı Kredi Yayınları, İstanbul.

Bilsel, F.C. (2010) “Henri Prost'un İstanbul Planlaması (19361951): Nazım Planlar ve Kentsel Operasyonlarla Kentin Yapısal Dönüşümü", Ed.:F.C. Bilsel and P. Pinon, Imparatorluk Başkentinden Cumhuriyet'in Modern Kentine: Henri Prost'un İstanbul Planlaması (1936-1951), İstanbul, pp.101-165.

Dinçer, i. (2011) "The Impact of Neoliberal Policies on Historic Urban Space: Areas of Urban Renewal in Istanbul", International Planning Studies, Vol: 16, No: 1, pp.43-60.

Duranay, N., Gürsel, E. and Ural, S. (1972) "Cumhuriyetten Bu Yana İstanbul Planlaması", Mimarlık, No: 7, pp.65-109.

Evliya Çelebi. (2014) Günümüz Türkçesiyle Evliya Çelebi Seyahatnamesi: İstanbul, Ed.: Seyit Ali Karaman and Yücel Dağlı, Yapı Kredi Yayınları, İstanbul.

İstanbul Site Management Directorate (2011) İstanbul Historic Peninsula Site Management Plan, İstanbul.

Köksal, G. (2007) “Yıpranma Halinin 'Yasal Düzeni'! Tarihi Dokuya Yaklaşımda Yeni Bir Tehdit: 5366 Sayılı Yasa", Mimar.ist, No: 26, pp.58-61.

Ortaylı, i. (2005) "Tarihsel Perspektiften Sur Dışı", Ed.: Burçak Evren, Surların Öte Yanı Zeytinburnu, İstanbul, Zeytinburnu Belediyesi Kültür Yayınları, pp.88-89.

Özbayoğlu, E. (2005) "Bizans Döneminde Zeytinburnu", Ed.: Burçak Evren, Surların Öte Yanı Zeytinburnu, İstanbul, Zeytinburnu Belediyesi Kültür Yayınları, pp.12-21.

Özçakır, Ö., Bilgin Altınöz, A. G. and Mignosa, A. (2018) "Political Economy of Renewal of Heritage Places in Turkey", METU Journal of the Faculty of Architecture (Advance Online), DOI: 10.4305/METU.JFA.2018.1.10.

Özvar, E. (2005) "Osmanlılar Zamanında Zeytinburnu", Ed.: Burçak Evren, Surların Öte Yanı Zeytinburnu, İstanbul: Zeytinburnu Belediyesi Kültür Yayınları, ss.42-55.

Tekeli, i. (2013) İstanbul'un Planlanmasının ve Gelişmesinin Öyküsü, Tarih Vakfi Yurt Yayınları, İstanbul.

Turnbull, S. (2004) The Walls of Constantinople A.D. 324-1453, Osprey Publishing Ltd.

Yelmen, H. (2005) "Kazlıçeşme", Ed.: Burçak Evren, Surların Öte Yanı Zeytinburnu, İstanbul, Zeytinburnu Belediyesi Kültür Yayınları, pp.58-87. 
Yetişkin Kubilay, A. (2009) İstanbul Haritaları 1422-1922, Denizler Kitabevi, İstanbul.

\section{Internet References}

URL-1. http://whc.unesco.org/en/list/356 (20.03.2018).

URL-2. http://www.alanbaskanligi.gov.tr (20.03.2018).

URL-3. http://www.kulturvarliklari.gov.tr/TR,43250/law-onconservation-by-renovation-and-use-by-revitaliza-.html (20.03.2018).

URL-4. https://oxfordbyzantinesociety.files.wordpress. com/2014/02/report_land_wal Is_whs.pdf (20.03.2018).

URL-5. https://istanbul-constantinople.culturalspot.org/home (20.03.2018).

URL-6. http://gecmisgunler.blogspot.com.tr/2013/07/takkeci-ibrahim-cavus-camii-topkapi.html (20.03.2018).

URL-7. http://istanbulermenivakiflari.org/tr/ (20.03.2018).

URL-8. http://www.baliklirum.com/VakifTarihce.aspx (20.03.2018).

URL-9. http://eski.zeytinburnu.istanbul/Sayfa/Fotograf-Galerisi/76/zeytinburnu-gorsel-galerileri/fotograf-galerisi.aspx (20.03.2018).

URL-10. http://www.kulturvarliklari.gov.tr/TR,43249/law-onthe-conservation-of-cultural-and-natural-propert-.html (20.03.2018).

URL-11.https://zdergisi.istanbul/makale/kultur-vadisi-projesi-o- dul-yolunda-58 (20.03.2018).

URL-12. http://www.zeytinburnu.istanbul/Belediye-Hizmetleri/ Projeler/Kultur-Vadisi-Projesi (20.03.2018).

URL-13. $\quad$ http://topkapiturkdunyasi.com/topkapi-tuerkduenyasi/eski-tuerk-çadırları/kırgız-çadırı.aspx (20.03.2018).

URL-14. http://www.beyazgayrimenkul.com.tr/merkezefendikonakları/DP_14/ (20.03.2018).

URL-15. http://www.zeytinburnu.istanbul/ZeytinburnuBelediyesine-Ait-Yatirim-ve-Hizmetler (20.03.2018).

URL-16. http://www.sinanasaygi.org/eserler_resimler_detay.asp?action=eserDetay \&ID=70 (20.03.2018).

URL-17. http://www.uzmim.net/projeler-klasor/103-istanbulplanetaryum/projeler3.html (20.03.2018).

URL-18. https://www.emlaknews.com.tr/haberler/ibb-sportoto-zeytinburnu-belediyesinden-3-dev-yatirim-299402/ (20.03.2018).

URL-19. http://portal.unesco.org/en/ev.php-URL ID $=13133 \& U R L$ DO=DO_TOPIC\&URL_SECTION $=201 . \mathrm{html}$ (20.03.2018).

URL-20. http://www.icomos.org.tr/Dosyalar/ ICOMOSTR_0885010001353670152.pdf (20.03.2018).

URL-21. http://www.icomos.org.tr/Dosyalar/ICOMOSTR 0209751001353671440.pdf (20.03.2018).

URL-22. http://whc.unesco.org/en/soc/270 (20.03.2018).

URL-23. http://www.fatih.bel.tr (20.03.2018). 